\title{
Impacts of biogenic polyunsaturated aldehydes on metabolism and community composition of particle-attached bacteria in coastal hypoxia
}

\author{
Zhengchao Wu ${ }^{1,2}$, Qian P. Li ${ }^{1,2,3}$, Zaiming Ge ${ }^{1,3}$, Bangqin Huang ${ }^{4}$, and Chunming Dong ${ }^{5}$ \\ ${ }^{1}$ State Key Laboratory of Tropical Oceanography, South China Sea Institute of Oceanology, \\ Chinese Academy of Sciences, Guangzhou, China \\ ${ }^{2}$ Southern Marine Science and Engineering Guangdong Laboratory (Guangzhou), Guangzhou, China \\ ${ }^{3}$ College of Marine Science, University of the Chinese Academy of Sciences, Beijing, China \\ ${ }^{4}$ Fujian Provincial Key Laboratory of Coastal Ecology and Environmental Studies, State Key Laboratory of Marine \\ Environmental Science, Xiamen University, Xiamen, China \\ ${ }^{5}$ Key Laboratory of Marine Genetic Resources, Third Institute of Oceanography, MNR, Xiamen, China
}

Correspondence: Qian P. Li (qianli@scsio.ac.cn)

Received: 24 June 2020 - Discussion started: 24 July 2020

Revised: 10 December 2020 - Accepted: 21 December 2020 - Published: 12 February 2021

\begin{abstract}
Eutrophication-driven coastal hypoxia has been of great interest for decades, though its mechanisms remain not fully understood. Here, we showed elevated concentrations of particulate and dissolved polyunsaturated aldehydes (PUAs) associated with the hypoxic waters in the bottom layer of a salt-wedge estuary. Bacterial respiration within the hypoxic waters was mainly contributed by particle-attached bacteria $(\mathrm{PAB})(>0.8 \mu \mathrm{m})$, with free-living bacteria $(0.2-$ $0.8 \mu \mathrm{m}$ ) only accounting for $25 \%-30 \%$ of the total rate. The concentrations of particle-adsorbed PUAs $\left(\sim 10 \mu \mathrm{mol} \mathrm{L}^{-1}\right)$ in the hypoxic waters were directly quantified for the first time based on large-volume filtration and subsequent on-site PUA derivation and extraction. PUA-amended incubation experiments for PAB $(>25 \mu \mathrm{m})$ associated with sinking or suspended particles retrieved from the low-oxygen waters were also performed to explore the impacts of PUAs on the growth and metabolism of PAB and associated oxygen utilization. We found an increase in cell growth of PAB in response to low-dose PUAs $\left(1 \mu \mathrm{mol} \mathrm{L}{ }^{-1}\right)$ but an enhanced cell-specific bacterial respiration and production in response to high-dose PUAs $\left(100 \mu \mathrm{mol} \mathrm{L}^{-1}\right)$. Improved cell-specific metabolism of $\mathrm{PAB}$ in response to high-dose PUAs was also accompanied by a shift of PAB community structure with increased dominance of the genus Alteromonas within the Gammaproteobacteria. We thus conclude that a high PUA concentration
\end{abstract}

associated with aggregate particles within the bottom layer may be crucial for some species within Alteromonas to regulate PAB community structure. The change in bacteria community could lead to an enhancement of oxygen utilization during the degradation of particulate organic matter and thus likely contribute to the formation of coastal hypoxia. These findings are potentially important for coastal systems with large river inputs, intense phytoplankton blooms driven by eutrophication, and strong hypoxia developed below the saltwedge front.

\section{Introduction}

Coastal hypoxia, defined as dissolved oxygen levels $<62.5 \mu \mathrm{mol} \mathrm{kg}^{-1}$, has become a worldwide problem in recent decades (Diaz and Rosenberg, 2008; Helm et al., 2011). It could affect diverse life processes from genes to ecosystems, resulting in the spatial and temporal change in marine food-web structures (Breitburg et al., 2018). Coastal deoxygenation is also tightly coupled with other global issues, such as global warming and ocean acidification (Doney et al., 2012). Formation and maintenance of eutrophication-derived hypoxia in the coastal waters should reflect the interaction between physical and biogeochemical processes (Kemp et 
al., 2009). Generally, seasonal hypoxia occurs in the coastal ocean when strong oxygen sinks are coupled with restricted resupply during periods of strong density stratification. Termination of the event occurs with oxygen resupply when stratification is eroded by vertical mixing (Fennel and Testa, 2019).

Bacterial respiration accounts for the largest portion of aquatic oxygen consumption and is thus pivotal for the development of hypoxia and oxygen minimum zones (Williams and del Giorgio, 2005; Diaz and Rosenberg, 2008). Generally, free-living bacteria (FLB, $0.2-0.8 \mu \mathrm{m}$ ) dominate the community respiration in many parts of the ocean (Robinson and Williams, 2005; Kirchman, 2008). Compared to the $\mathrm{FLB}$, the role of particle-attached bacteria (PAB, >0.8 $\mu \mathrm{m})$ on community respiration is less addressed, particularly in the coastal oceans. In some coastal waters, PAB can be more important than the FLB with a higher metabolic activity that might affect carbon cycle through organic matter remineralization (Garneau et al., 2009; Lee et al., 2015). PAB was found more abundant than the FLB with a higher diversity near the mouth of the Pearl River estuary (PRE) (Li et al., 2018; Liu et al., 2020; Zhang et al., 2016). An increased contribution of PAB to respiration relative to FLB can occur during the development of coastal phytoplankton bloom (Huang et al., 2018). In the Columbia River estuary, the particleattached bacterial activity could be 10-100-fold higher than that of its free-living counterparts, leading to its dominant role in organic detritus remineralization (Crump et al., 1998). Therefore, it is crucial to assess the respiration process associated with PAB and its controlling factors in these regions to fully understand oxygen utilization in the hypoxic area with an intense supply of particulate organic matter.

There is an increasing area of seasonal hypoxia in the nearshore bottom waters of the Pearl River estuary and the adjacent northern South China Sea (NSCS) (Yin et al., 2004; Zhang and Li, 2010; Su et al., 2017). The hypoxia is generally developed at the bottom of the salt wedge where downward mixing of oxygen is restrained due to increased stratification and where there is an accumulation of eutrophicationderived organic matter due to flow convergence driven by local hydrodynamics (Lu et al., 2018). Besides physical and biogeochemical conditions, aerobic respiration is believed to be the ultimate cause of hypoxia here (Su et al., 2017). Thus, microbial respiration had been strongly related to the consumption of bulk dissolved organic carbon in the PRE hypoxia (He et al., 2014).

Phytoplankton-derived polyunsaturated aldehydes (PUAs) are known to affect marine microorganisms over various trophic levels by acting as infochemicals and/or by chemical defenses, which strengthen their potential importance in natural environments (Ribalet et al., 2008; Ianora and Miralto, 2010; Edwards et al., 2015; Franzè et al., 2018). PUAs are produced by stressed diatoms during the oxidation of membrane polyunsaturated fatty acids (PUFAs) by lipoxygenase (Pohnert, 2000) and are released from the surface of particles to the seawater by diffusion. A perennial bloom of PUA-producing diatoms near the mouth of the PRE (Wu and $\mathrm{Li}, 2016$ ) should support the importance of PUAs relative to other phytoplankton-derived organic compounds, such as karlotoxin by dinoflagellates, cyanotoxin by cyanobacteria, and dimethylsulfoniopropionate mainly by prymnesiophytes. Besides PUAs, there are other signaling molecules that may potentially affect bacterial activities in the low-oxygen waters, such as 2-n-pentyl-4-quinolinol (PQ) and acylated homoserine lactones (AHLs). PQ could be less important here in terms of hypoxia formation as it is generally produced as antibiosis by PAB such as Alteromonas sp. to inhibit respirations of other PAB (Long et al., 2003). AHLs could also play a less important role here since the AHL-mediated quorum sensing could be constrained by a large $\mathrm{pH}$ fluctuation from 7.2 to 8.8 in the bottom waters of the PRE (Decho et al., 2009).

The level of PUAs in the water column is inhomogeneous, varying from sub-nanomolar offshore to nanomolar near shore (Vidoudez et al., 2011; Wu and Li, 2016; Bartual et al., 2018) and to micromolar associated with particle hotspots (Edwards et al., 2015). The strong effect of PUAs on bacterial growth, production, and respiration has been well demonstrated in laboratory studies (Ribalet et al., 2008) and field studies (Balestra et al., 2011; Edwards et al., 2015). A nanomolar level of PUAs recently reported in the coastal waters outside the PRE was hypothesized to affect oxygen depletion by promoting microbial utilization of organic matter in the bottom waters (Wu and $\mathrm{Li}, 2016$ ). Meanwhile, the actual role of PUAs on bacterial metabolism within the bottom hypoxia remains largely unexplored.

In this study, we investigate the particle-attached bacteria within the core of the hypoxic waters by exploring the linkage between PUAs and bacterial oxygen utilization on the suspended organic particles. There are three specific questions to address here. What are the relative roles of PAB and FLB on bacterial respiration in the hypoxic waters? What are the actual levels of PUAs in the hypoxic waters? What are the responses of PAB to PUAs in the hypoxic waters? For the first question, size-fractionated bacterial respiration rates were estimated for both FLB $(0.2-0.8 \mu \mathrm{m})$ and PAB $(>0.8 \mu \mathrm{m})$ in the hypoxic waters. For the second question, the concentrations of particulate and dissolved PUAs within the hypoxic waters were measured in the field. Besides, the hotspot PUA concentration associated with the suspended particles within the hypoxic waters was directly quantified for the first time using large-volume filtration and subsequent on-site derivation and extraction. For the third question, field PUA-amended incubation experiments were conducted for PAB $(>25 \mu \mathrm{m})$ retrieved from the low-oxygen waters. We focused on particles of $>25 \mu \mathrm{m}$ to explore the role of PUAs on PAB associated with sinking aggregates and large suspended particles (it may not be directly comparable to other size cutoffs in the literature). The doses of PUA treatments were selected to represent the actual lev- 
Table 1. Summary of treatments in the experiments of exogenous PUA additions for the low-oxygen waters at station Y1 during June 2019. The PUA solution includes heptadienal (C7_PUA), octadienal (C8_PUA), and decadienal (C10_PUA) with the mole ratios of $10: 1: 10$.

\begin{tabular}{lll}
\hline & & Treatment \\
\hline 1 & Control (methanol) & methanol \\
2 & Low-dose PUAs (methanol) & 2 mM PUAs in methanol \\
3 & High-dose PUAs (methanol) & 200 mM PUAs in methanol \\
\hline
\end{tabular}

els of PUA hotspots to assess the PAB responses (including bacterial abundance, respiration, production, and community composition) to the exogenous PUAs in the hypoxic waters. By synthesizing these experimental results with the change in water-column biogeochemistry, we hope to explore the underlying mechanism for particle-adsorbed PUAs influencing community structure and metabolism of PAB in the lowoxygen waters, as well as to understand its contribution to coastal deoxygenation of the NSCS shelf sea.

\section{Methods}

\subsection{Descriptions of field campaigns and sampling approaches}

Field survey cruises were conducted in the PRE and the adjacent NSCS during 17-28 June 2016 and 18 June-2 July 2019 (Fig. 1). Briefly, vertical profiles of temperature, salinity, dissolved oxygen, and turbidity were acquired from a SeaBird 911 rosette sampling system. The oxygen sensor data were corrected by field titration measurements during the cruise. Water samples at various depths were collected using 6 or $12 \mathrm{~L}$ (12 or 24 positions) Niskin bottles attached to the Rosette sampler. Surface water samples were collected at $\sim 1$ or $5 \mathrm{~m}$ depth, while bottom water samples were obtained at depths $\sim 4 \mathrm{~m}$ above the bottom. Chlorophyll- $a$ (Chla) samples were taken at all depths at all stations, and nutrients were also sampled, except at a few discrete stations. For the 2016 cruise, samples for particulate PUAs (pPUAs) were collected at all depths close to station X1 (Fig. 1a). During the summer of 2019, vertical profiles of pPUAs and dissolved PUAs (dPUAs) were determined at Y1 in the hypoxic zone and Y2 outside the hypoxic zone with field PUA-amended experiments conducted at Y1 (Fig. 1b). For station Y1, the middle layer was defined as $12 \mathrm{~m}$ with the bottom layer as $25 \mathrm{~m}$. At this station, samples at different depths were collected for determining the size-fractionated respiration rates and the whole water bacterial taxonomy.

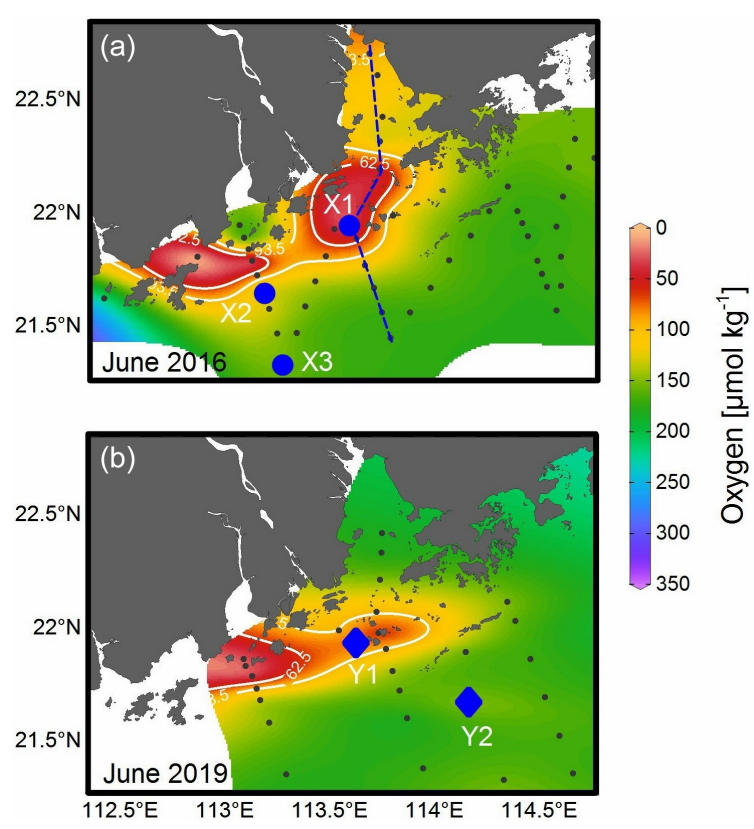

Figure 1. Sampling map of the Pearl River estuary and the adjacent northern South China Sea during (a) 17-28 June 2016 and (b) 18 June-2 July 2019. Contour shows the bottom oxygen distribution with white lines highlighting the levels of $93.5 \mu \mathrm{mol} \mathrm{kg}{ }^{-1}$ (oxygen-deficient zone) and $62.5 \mu \mathrm{mol} \mathrm{kg}^{-1}$ (hypoxic zone); dashed line in panel (a) is an estuary-to-shelf transect with blue dots for three stations with bacterial metabolic rate measurements; diamonds in panel (b) are two stations with vertical pPUA and dPUA measurements, with Y1 being the station for PUA-amended experiments.

\subsection{Determination of chlorophyll- $a$ and dissolved nutrients}

For Chl- $a$ analyses, $500 \mathrm{~mL}$ of water sample was gently filtered through a $0.7 \mu \mathrm{m}$ Whatman GF/F filter. The filter was then wrapped by a piece of aluminum foil and stored at $-20{ }^{\circ} \mathrm{C}$ on board. Chl- $a$ was extracted at $4{ }^{\circ} \mathrm{C}$ in the dark for $24 \mathrm{~h}$ using $5 \mathrm{~mL}$ of $90 \%$ acetone. After being centrifuged at $4000 \mathrm{rpm}$ for $10 \mathrm{~min}$, Chl- $a$ was measured using a standard fluorometric method with a Turner Designs fluorometer (Parsons et al., 1984). Water samples for nutrients were filtered through $0.45 \mu \mathrm{m}$ Nucleopore filters and stored at $-20^{\circ} \mathrm{C}$. Nutrient concentrations including nitrate plus nitrite, phosphate, and silicate were measured using a segmented-flow nutrient AutoAnalyzer (Seal AA3, Bran + Luebbe GmbH).

\subsection{Sampling and measurements of particulate and dissolved PUAs in $1 \mathrm{~L}$ seawater}

We used a similar protocol of $\mathrm{Wu}$ and $\mathrm{Li}$ (2016) for pPUA and dPUA collection, pretreatment, and determination. Briefly, 2-4L of water sample went through a GF/C filtration with both the filter and the filtrate collected separately. The filter was rinsed by the derivative solution with 
the suspended particle samples collected in a glass vial. After adding an internal standard, the samples in the vial were frozen and thawed three times to mechanically break the cells for pPUAs. The filtrate from the GF/C filtration was also added with an internal standard and transferred to a C18 solid-phase extraction cartridge. The elute from the cartridge with the derivative solution was saved in a glass vial for dPUAs. Both pPUA and dPUA samples were frozen and stored at $-20^{\circ} \mathrm{C}$.

In the laboratory, the pPUA sample was thawed with the organic phase extracted. After the solvent was evaporated with the sample concentrated and re-dissolved in hexane, pPUAs were determined using gas chromatography and mass spectrometry (Agilent Technologies Inc., USA). Standards series were prepared by adding certain amounts of three major PUAs to the derivative solution and went through the same pretreatment and extraction steps as samples. Derivatives of dPUAs were extracted and measured by similar methods to pPUAs, except that the calibration curves of dPUAs were constructed separately. The units of pPUAs and dPUAs are $\mathrm{nmol} \mathrm{L}^{-1}$ (nmol PUA in $1 \mathrm{~L}$ seawater).

\subsection{Particle collections by large-volume filtrations in hypoxia waters}

Large volumes $(\sim 300 \mathrm{~L})$ of the middle $(12 \mathrm{~m})$ and the bottom $(25 \mathrm{~m})$ waters within the hypoxia zone were collected by Niskin bottles at station Y1. For each layer, the water sample was quickly filtered through a sterile fabric screen $(25 \mu \mathrm{m}$ filter) on a disk filter equipped with a peristaltic pump to qualitatively obtain particles of $>25 \mu \mathrm{m}$. Larger zooplankters were picked off immediately. The particle samples were gently back-flushed three times off the fabric screen using particle-free seawater (obtained using a $0.2 \mu \mathrm{m}$ filtration of the same local seawater) into a sterile $50 \mathrm{~mL}$ sampling tube.

The volume of total particles from large-volume filtration was measured as follows: the collected particle in the $50 \mathrm{~mL}$ tube was centrifuged for $1 \mathrm{~min}$ at a speed of 3000 revolutions per minute (rpm) with the supernatant saved (Hmelo et al., 2011). The particle sample was resuspended as slurry by gently shaking and was transferred into a sterile $5 \mathrm{~mL}$ graduated centrifuge tube. The sample was centrifuged again by the same centrifuging speed with the final volume of the total particles recorded. The unit for the total particle volume is milliliter $(\mathrm{mL})$.

All the particles were transferred back to the sterile $50 \mathrm{~mL}$ centrifuge tube (so as all the supernatants) with $0.2 \mu \mathrm{m}$ filtered seawater, which was used for subsequent measurements of particle-adsorbed PUAs as well as for PUA-amended incubation experiments of particle-attached bacteria.

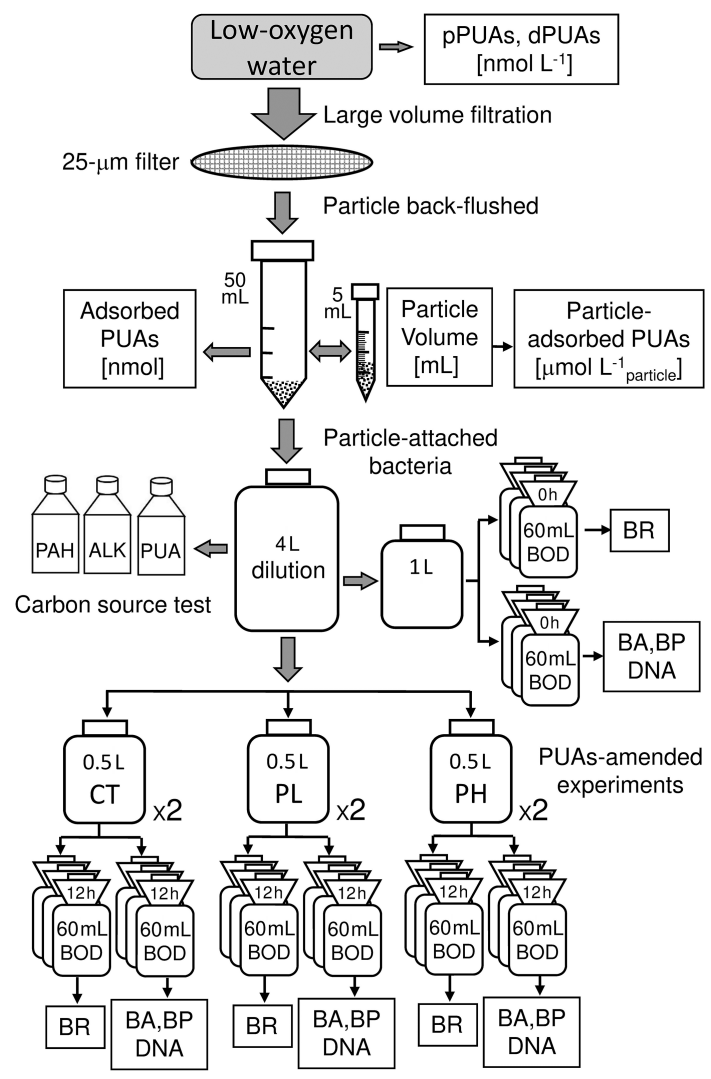

Figure 2. Procedure of large-volume filtration and subsequent experiments. A large volume of the low-oxygen water was filtered through a $25 \mu \mathrm{m}$ filter to obtain the particle-adsorbed PUAs and the particle-attached bacteria (PAB). The carbon-source test of PUA for the inoculated PAB includes the additions of PUA, alkanes (ALKs), and polycyclic aromatic hydrocarbons (PAHs). PUA-amended experiments for PAB include control (CT), low-dose (PL), and highdose (PH) PUAs. Samples in the biological oxygen demand (BOD) bottles at the end of the experiment were analyzed for bacterial respiration (BR), abundances (BA), production (BP), and DNA. Note that pPUAs and dPUAs are particulate and dissolved PUAs in the seawater.

\subsection{Measurements of particle-adsorbed PUAs}

After gently shaking, $3 \mathrm{~mL}$ of sample in the $50 \mathrm{~mL}$ sampling tube (see Sect. 2.4) was used for the analyses of particleadsorbed PUA concentration (two replicates) according to the procedure shown in Fig. 2 (modified from the protocols of Edwards et al., 2015, and $\mathrm{Wu}$ and $\mathrm{Li}, 2016$ ). The sample $(3 \mathrm{~mL})$ was transferred to $50 \mathrm{~mL}$ centrifuge tubes for PUA derivatization on board. An internal standard of benzaldehyde was added to obtain a final concentration of $10 \mu \mathrm{m}$. The aldehydes in the samples were derivatized by the addition of O-(2,3,4,5,6-pentafluorobenzyl) hydroxylamine hydrochloride solution in deionized water $(\mathrm{pH}=7.5)$. The reaction was performed at room temperature for $15 \mathrm{~min}$ (shaking slightly for mixing every $5 \mathrm{~min}$ ). Then $2 \mathrm{~mL}$ sulfuric acid 
$(0.1 \%)$ solution was added to a final concentration of $0.01 \%$ acid ( $\mathrm{pH}$ of 2-3) to avoid new PUAs induced by enzymatic cascade reactions. The derivate samples were subsequently sonicated for $3 \mathrm{~min}$ before the addition of $20 \mathrm{~mL}$ hexane, and the upper organic phase of the extraction was transferred to a clean tube and stored at $-20^{\circ} \mathrm{C}$.

Upon returning to the laboratory, the adsorbed PUAs on these particles (undisrupted PUAs) were determined with the same analytical methods as those for the disrupted pPUAs (freeze-thaw methods to include the portion of PUAs eventually produced as cells die, $\mathrm{Wu}$ and $\mathrm{Li}, 2016$ ) except for the freeze-thaw step. A separate calibration curve was made for the undisrupted PUA derivates. A standard series of heptadienal, octadienal, and decadienal $(0,0.1,0.5,1.0,2.5$, 5.0, $10.0,25.0 \mathrm{nmol} \mathrm{L}^{-1}$ ) was prepared before each analysis by diluting a relevant amount of the PUA stock solution (methanolic solution) with deionized water. These standard solutions were processed through all the same experimental steps as those mentioned above for derivation, extraction, and measurement of the undisrupted PUA sample. The unit for the undisrupted PUAs is nmol L $\mathrm{L}^{-1}$. The total amount of the undisrupted PUAs in the $50 \mathrm{~mL}$ sampling tube was the product of the measured concentration and the total volume of the sample.

The hotspot PUA concentration associated with the aggregate particles is defined as the PUA concentration in the volume of the water parcel displaced by these particles. Therefore, the final concentration of particle-adsorbed PUAs in the water column, defined as PUAs $\left(\mu \mathrm{mol} \mathrm{L}^{-1}\right)$, should be equal to the moles of particle-adsorbed PUAs (nmol, the undisrupted PUAs) divided by the volume of particles $(\mathrm{mL})$.

\subsection{Incubation of particle-attached bacteria with PUA treatments}

The impact of PUAs on microbial growth and metabolisms in the hypoxia zone was assessed by field incubation of particle-attached bacteria on particles of $>25 \mu \mathrm{m}$ collected from large-volume filtration with direct additions of low or high doses of PUAs $\left(1\right.$ or $\left.100 \mu \mathrm{mol} \mathrm{L}^{-1}\right)$ on 29 June 2019 (Fig. 2).

A sample volume of $\sim 32 \mathrm{~mL}$ in the centrifuge tube (Sect. 2.4) was transferred to a sterile Nalgene bottle before being diluted by particle-free seawater to a final volume of $4 \mathrm{~L}$. About $3.2 \mathrm{~L}$ of the sample solution was transferred into four sterile $1 \mathrm{~L}$ Nalgene bottles (each with $800 \mathrm{~mL}$ ). One $1 \mathrm{~L}$ bottle was used for determining the initial conditions: after gentle shaking, the solution was transferred into six biological oxygen demand (BOD) bottles with three for initial oxygen concentration (fixed immediately by Winkler reagents) and the other three for initial bacterial abundance, production, and community structure. The other three $1 \mathrm{~L}$ bottles were used for three different treatments (each with two replicates in two $0.5 \mathrm{~L}$ bottles): the first one served as the control with the addition of $200 \mu \mathrm{L}$ methanol, the second one with $200 \mu \mathrm{L}$ low-dose PUA solution, and the third one with $200 \mu \mathrm{L}$ high-dose PUA solution (Table 1). We should note that the methanol percentage $(0.05 \% v / v)$ here is higher than its natural level in seawater although no substantial change in bacterial community was found.

The solution in each of the three treatments $(0.5 \mathrm{~L}$ bottles $)$ was transferred to six parallel replicates by $60 \mathrm{~mL}$ BOD bottles. These BOD bottles were incubated at in situ temperature in the dark for $12 \mathrm{~h}$. At the end of each incubation experiment, three of the six BOD bottles were used for determining the final oxygen concentrations with the other three for the final bacterial abundance, production, and community structure.

To test the possibility of PUAs as carbon sources for bacterial utilization, a minimal medium was prepared with only sterile artificial seawater but not any organic carbons (Dyksterhouse et al., 1995). A volume of $375 \mu \mathrm{L}$ sample (from the above $4 \mathrm{~L}$ sample solution) was inoculated in the minimal medium amended with heptadienal in a final concentration of about $200 \mu \mathrm{mol} \mathrm{L}^{-1}$. This PUA level was close to the hotspot PUAs of $240 \mu \mathrm{mol} \mathrm{L}-1$ found in the suspended particles of a station near the PRE. It was also comparable to the hotspot PUAs of $25.7 \mu \mathrm{mol} \mathrm{L}^{-1}$ in the temperate west North Atlantic (Edwards et al., 2015). For comparisons, the same amount of sample was also inoculated in the minimal medium $(75 \mathrm{~mL}$ ) amended with an alkane mixture (ALK, $n$-pentadecane and $n$-heptadecane) at a final concentration of $0.25 \mathrm{~g} \mathrm{~L}^{-1}$ or with a mixture of polycyclic aromatic hydrocarbons (PAHs, naphthalene and phenanthrene) at a final concentration of $200 \mathrm{ppm}$. These experiments were performed in the dark at room temperature for over $30 \mathrm{~d}$. Significant turbidity changes in the cell culture bottle over incubation time are observed if there is a carbon source for bacterial growth.

\subsection{Measurements of bacteria-related parameters}

\subsubsection{Bacterial abundance}

At the end of the $12 \mathrm{~h}$ incubation period, a $2 \mathrm{~mL}$ sample from each BOD bottle was preserved in $0.5 \%$ glutaraldehyde. The fixation lasted for half of an hour at room temperature before being frozen in liquid $\mathrm{N}_{2}$ and stored in $\mathrm{a}-80^{\circ} \mathrm{C}$ freezer. In the laboratory, the samples were performed through a previously published procedure for detaching particle-attached bacteria (Lunau et al., 2005), which had been proved effective for samples with high particle concentrations. To break up particles and attached bacteria, $0.2 \mathrm{~mL}$ pure methanol was added to the $2 \mathrm{~mL}$ sample and vortexed. The sample was then incubated in an ultrasonic bath $(35 \mathrm{kHz}, 2 \times 320 \mathrm{~W}$ per period) at $35^{\circ} \mathrm{C}$ for $15 \mathrm{~min}$. Subsequently, the tube sample was filtered with a $50 \mu \mathrm{m}$ filter to remove large detrital particles. The filtrate samples for surface-associated bacteria cells were diluted by $5-10$-fold using a TE buffer solution and stained with $0.01 \%$ SYBR Green I in the dark at room temperature 
for $40 \mathrm{~min}$. With the addition of $1 \mu \mathrm{m}$ beads, bacterial abundance (BA) of the samples was counted by a flow cytometer (Beckman Coulter CytoFLEX S) with bacteria detected on a plot of green fluorescence versus side scatter (Marie et al., 1997). The precision of the method estimated by the coefficient of variation (CV\%) was generally less than $5 \%$.

For bulk-water bacteria abundance, $1.8 \mathrm{~mL}$ of seawater sample was collected after a $20 \mu \mathrm{m}$ prefiltration. The sample was transferred to a $2 \mathrm{~mL}$ centrifuge tube and fixed by adding $20 \mu \mathrm{L}$ of $20 \%$ paraformaldehyde before storage in a $-80^{\circ} \mathrm{C}$ freezer. In the laboratory, $300 \mu \mathrm{L}$ of the sample after thawing was used for staining with SYBR Green and analyzed using the same flow cytometry method as above (Marie, et al., 1997).

\subsubsection{Bacterial respiration}

For BOD samples, bacterial respiration (BR) was calculated based on the oxygen decline during the $12 \mathrm{~h}$ incubation and was converted to carbon units with the respiratory quotient assumed equal to 1 (Hopkinson, 1985). Dissolved oxygen was determined by a high-precision Winkler titration apparatus (Metrohm-848, Switzerland) based on the classic method (Oudot et al., 1988). We should mention that BR could be overestimated if phytoplankton and microzooplankton were present in the particle aggregates of $>25 \mu \mathrm{m}$. However, this effect could be relatively small because the raw seawater in the hypoxic zone had very low chlorophyll $a$ and because there was virtually not much microzooplankton in the sample (confirmed by FlowCAM).

The method for the estimation of the bulk water bacterial respiration at stations $\mathrm{X} 1, \mathrm{X} 2$, and $\mathrm{X} 3$ can be found in Xu et al. (2018). For the bulk water at station Y1, the size-fractionated respiration rates, including free-living bacteria of $0.2-0.8 \mu \mathrm{m}$ and a particle-associated community of $>0.8 \mu \mathrm{m}$ (we assumed that they were mostly PAB given the low phytoplankton chlorophyll $a$ of the sample and the absence of zooplankton during the filtration), were estimated based on the method of García-Martín et al. (2019). Four $100 \mathrm{~mL}$ polypropylene bottles were filled with seawater. One bottle was immediately fixed by formaldehyde. After $15 \mathrm{~min}$, the sample in each bottle was incubated in the dark at the in situ temperature after the addition of the iodo-nitro-tetrazolium (INT) salt at a final concentration of $0.8 \mathrm{mmol} \mathrm{L}^{-1}$. The incubation reaction lasted for $1.5 \mathrm{~h}$ before being stopped by formaldehyde. After $15 \mathrm{~min}$, all the samples were sequentially filtered through 0.8 and $0.2 \mu \mathrm{m}$ pore size polycarbonate filters and stored frozen until further measurements by spectrophotometry.

\subsubsection{Bacterial production}

Bacterial production (BP) was determined using a modified protocol of the ${ }^{3} \mathrm{H}$-leucine incorporation method (Kirchman, 1993). Four $1.8 \mathrm{~mL}$ aliquots of the sample were col- lected by pipet from each BOD incubation and added to $2 \mathrm{~mL}$ sterile microcentrifuge tubes, which were incubated with ${ }^{3} \mathrm{H}$-leucine (in a final concentration of $4.65 \mu \mathrm{mol} \mathrm{Leu} \mathrm{L}{ }^{-1}$, PerkinElmer, USA). One tube served as the control and was fixed by adding $100 \%$ trichloroacetic acid (TCA) immediately (in a final concentration of $5 \%$ ). The other three were terminated with TCA at the end of the $2 \mathrm{~h}$ dark incubation. Samples were filtered onto $0.2 \mu \mathrm{m}$ polycarbonate filters and then rinsed twice with $5 \%$ TCA and three times with $80 \%$ ethanol (Huang et al., 2018) before being stored at $-80^{\circ} \mathrm{C}$. In the laboratory, the filters were transferred to scintillation vials with $5 \mathrm{~mL}$ of Ultima Gold scintillation cocktail. The incorporated ${ }^{3} \mathrm{H}$ was determined using a Tri-Carb 2800TR liquid scintillation counter. Bacterial production was calculated with the previous published leucine-to-carbon empirical conversion factors of $0.37 \mathrm{~kg}$ of carbon per mole of leucine in the study area (Wang et al., 2014). Bacterial carbon demand (BCD) was calculated as the sum of BP and BR. Bacterial growth efficiency (BGE) was equated to BP/BCD.

\subsubsection{Bacterial community structure}

At the end of incubation, the DNA sample was obtained by filtering $30 \mathrm{~mL}$ of each BOD water sample via a $0.22 \mu \mathrm{m}$ Millipore filter, which was preserved in a cryovial with the DNA protector buffer and stored at $-80^{\circ} \mathrm{C}$. DNA was extracted using the DNeasy PowerWater Kit with genomic amplification by polymerase chain reaction (PCR). The V3 and V4 fragments of bacterial 16S rRNA were amplified at $94^{\circ} \mathrm{C}$ for $2 \mathrm{~min}$ and followed by 27 cycles of amplification $\left(94^{\circ} \mathrm{C}\right.$ for $30 \mathrm{~s}, 55^{\circ} \mathrm{C}$ for $30 \mathrm{~s}$, and $72{ }^{\circ} \mathrm{C}$ for $60 \mathrm{~s}$ ) before a final step of $72^{\circ} \mathrm{C}$ for $10 \mathrm{~min}$. Primers for amplification included 341F (CCTACGGGNGGCWGCAG) and 805R (GACTACHVGGGTATCTAATCC). Reactions were performed in a $10 \mu \mathrm{L}$ mixture containing $1 \mu \mathrm{L}$ TopTaq Buffer, $0.8 \mu \mathrm{L}$ dNTPs, $10 \mu \mathrm{m}$ primers, $0.2 \mu \mathrm{L}$ Taq DNA polymerase, and $1 \mu \mathrm{L}$ template DNA. Three parallel amplification products for each sample were purified by an equal volume of AMPure XP magnetic beads. Sample libraries were pooled in equimolar and paired-end sequenced $(2 \times 250 \mathrm{bp})$ on an Illumina MiSeq platform.

High-quality sequencing data were obtained by filtering on the original offline data. Briefly, the raw data were preprocessed using TrimGalore to remove reads with qualities of less than 20 and FLASH2 to merge paired-end reads. Besides, the data were also processed using USEARCH to remove reads with a total base error rate of greater than 2 and short reads with a length of less than $100 \mathrm{bp}$ and using mothur to remove reads containing more than $6 \mathrm{bp}$ of $\mathrm{N}$ bases. We further used UPARSE to remove the singleton sequence to reduce the redundant calculation during the data processing. Sequences with similarity greater than $97 \%$ were clustered into the same operational taxonomic units (OTUs). R software was used for community composition analysis. 
DNA samples for the bulk bacteria $(>0.2 \mu \mathrm{m})$ and PAB on particles of $>25 \mu \mathrm{m}$ at station Y1 were also collected for bacterial community analysis using the same method described above. Methods for the bulk water bacterial community analyses at stations X1, X2, and X3 during the 2016 cruise can be found in the published paper of Xu et al. (2018).

\subsection{Statistical analysis}

All statistical analyses were performed using the statistical software SPSS (version 13.0, SPSS Inc., Chicago, IL, USA). A Student's $t$ test with a two-tailed hypothesis was used when comparing PUA-amended treatments with the control or comparing stations inside and outside the hypoxic zone, with the null hypothesis being rejected if the probability $(p)$ is less than 0.05 . We consider $p$ of $<0.05$ as significant and $p$ of $<0.01$ as strongly significant. Ocean Data View with the extrapolation model DIVA gridding method was used to contour the spatial distributions of physical and biogeochemical parameters.

\section{Results}

\subsection{Characteristics of hydrography, biogeochemistry, and bulk bacteria community in the hypoxic zone}

During our study periods, there was a large body of low-oxygen bottom water with the strongest hypoxia $\left(<62.5 \mu \mathrm{mol} \mathrm{kg}{ }^{-1}\right.$ ) on the western shelf of the PRE (Fig. 1), which was relatively similar among different summers of 2016 and 2019 (Fig. 1). For vertical distribution, a strong salt-wedge structure was found over the inner shelf (Fig. 3a, d) with fresh water on the shore side due to intense river discharge. Bottom waters with oxygen deficiency $(<93.5 \mu \mathrm{mol}$ $\mathrm{kg}^{-1}$ ) occurred below the lower boundary of the salt wedge and expanded $\sim 60 \mathrm{~km}$ offshore (Fig. 3e). In contrast, a surface high-Chl- $a$ patch $\left(6.3 \mu \mathrm{gL}^{-1}\right)$ showed up near the upper boundary of the front, where there was enhanced watercolumn stability, low turbidity, and high nutrients (Fig. 3b, c). Therefore, there was a spatial mismatch between the subsurface hypoxic zone (Fig. 3e) and the surface chlorophyll bloom (Fig. 3f) during the estuary-to-shelf transect, as both the surface Chl- $a$ and oxygen right above the hypoxic zones at the bottom boundary of the salt wedge were not themselves maxima.

There were much higher rates of respiration $(\mathrm{BR})(t=7.8$, $n=9, p<0.01)$ and production (BP) $(t=13.0, n=9, p<$ 0.01 ) for the bulk bacterial community (including FLB and $\mathrm{PAB})$ in the bottom waters of $\mathrm{X} 1$ within the hypoxic core than those of $\mathrm{X} 2$ and $\mathrm{X} 3$ outside the hypoxic zone during June 2016 (Fig. 4, modified from data of Xu et al., 2018). The size-fractionated respiration rates were quantified at station Y1 during the 2019 cruise (Fig. S1) to distinguish the different roles of FLB and PAB on bacterial respiration in the hypoxic waters. Our results suggested that bacterial res- piration within the hypoxic waters was largely contributed by PAB $(>0.8 \mu \mathrm{m})$, which was about $2.3-3$-fold higher than that by FLB $(0.2-0.8 \mu \mathrm{m})$.

The bulk bacterial composition of the bottom water of X1 during the 2016 cruise with $78 \%$ of Alphaproteobacteria ( $\alpha$-Pro), $15 \%$ of Gammaproteobacteria ( $\gamma$-Pro), and $6 \%$ of Bacteroidetes was significantly different from those of X2 and X3 (91\% $\alpha$-Pro, $5 \% \gamma$-Pro, and 2\% Bacteroidetes), although their bacterial abundances were about the same (Fig. 4). Compared to that of the 2016 cruise, there was a different taxonomic composition of the bulk bacterial community in the hypoxic waters of the 2019 cruise with on average $33 \%$ of $\alpha$-Pro, $25 \%$ of $\gamma$-Pro, and $14 \%$ of Bacteroidetes. Furthermore, there was a substantially different taxonomic composition for PAB $(>25 \mu \mathrm{m})$ with on average $66 \%$ of $\gamma$ Pro, $22 \%$ of $\alpha$-Pro, and $4 \%$ of Bacteroidetes (Fig. S2a). In particular, there was an increase in $\gamma$-Pro but a decrease in $\alpha$-Pro and Bacteroidetes in the PAB $(>25 \mu \mathrm{m})$ relative to the bulk bacterial community. On the genus level, the PAB ( $>25 \mu \mathrm{m}$ ) was largely dominated by the Alteromonas group in both the middle and bottom waters (Fig. S2b).

\subsection{PUA concentrations in the hypoxic zone}

Generally, there were significantly higher pPUAs of $0.18 \mathrm{nmol} \mathrm{L}^{-1}(t=3.20, n=10, p<0.01)$ and dPUAs of $0.12 \mathrm{nmol} \mathrm{L}^{-1}(t=7.61, n=8, p<0.01)$ in the hypoxic waters than in the nearby bottom waters without hypoxia (0.02 and $\left.0.01 \mathrm{nmol} \mathrm{L}^{-1}\right)$. Vertical distributions of pPUAs and dPUAs in the bulk seawater are shown for two stations (Y1 and Y2) inside and outside the hypoxic zone (Fig. 1). Nanomolar levels of pPUAs and dPUAs were found in the water column in both stations (Fig. 5e, f). There were high pPUAs and dPUAs in the bottom hypoxic waters of station Y1 (Fig. 5e, f) together with locally elevated turbidity (Fig. 3b) when compared to the bottom waters outside, which is likely a result of particle resuspension. For station Y2 outside the hypoxia, we found negligible pPUAs and dPUAs at depths below the mixed layer (Fig. 5e, f), which could be due to PUA dilution by the intruded subsurface seawater.

Particle-adsorbed PUAs in the low-oxygen waters were quantified for the first time with the direct particle volume estimated by large-volume filtration (see the method section), which would reduce the uncertainty associated with the particle volume calculated by empirical equations derived for marine-snow particles (Edward et al., 2015). We found high levels of particle-adsorbed PUAs $\left(\sim 10 \mu \mathrm{mol} \mathrm{L}^{-1}\right)$ in these waters (Fig. 6), which were orders of magnitude higher than the bulk water pPUA or dPUA concentrations $\left(<0.3 \mathrm{nmol} \mathrm{L}^{-1}\right.$, Fig. 5e, f). Particle-adsorbed PUAs of the low-oxygen waters mainly consisted of heptadienal (C7_PUA) and octadienal (C8_PUA). 


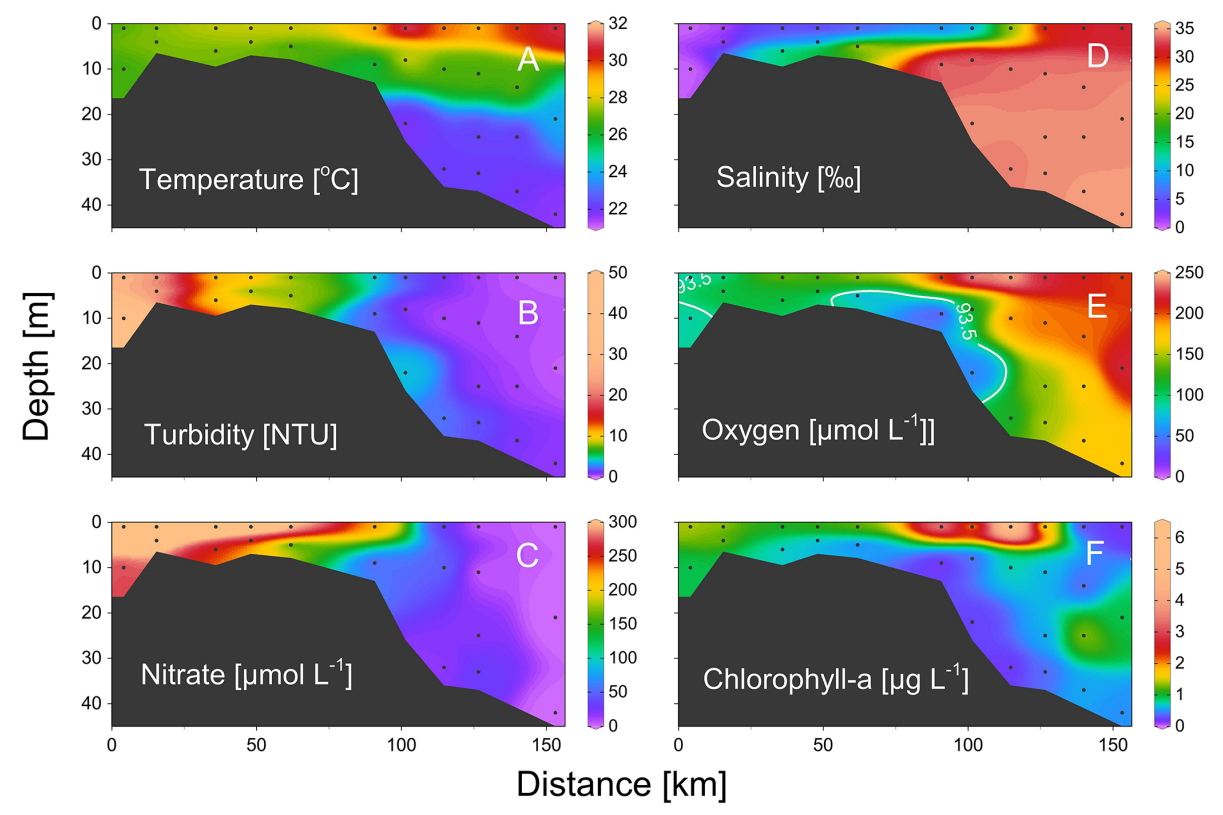

Figure 3. Vertical distributions of (a) temperature, (b) turbidity, (c) nitrate, (d) salinity, (e) dissolved oxygen, and (f) chlorophyll $a$ from the estuary to the shelf of the NSCS during June 2016. Section locations are shown in Fig. 1; the white line in panel (d) shows the area of oxygen-deficiency zone $\left(<93.5 \mu \mathrm{mol} \mathrm{kg}{ }^{-1}\right)$.

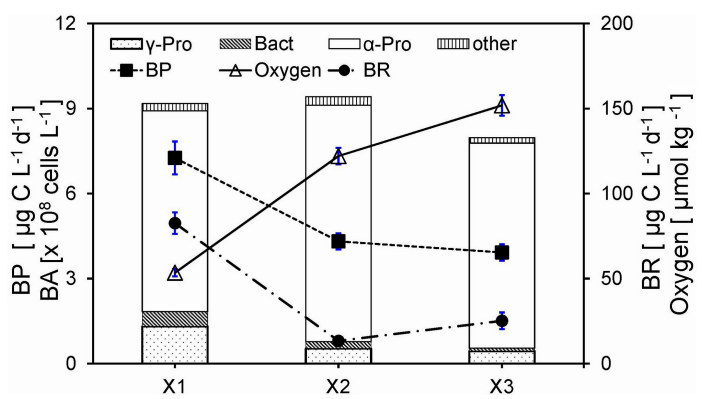

Figure 4. Comparisons of oxygen, bulk bacterial respiration (BR) and production (BP), and bulk bacterial abundances (BAs) of Alphaproteobacteria ( $\alpha$-Pro), Gammaproteobacteria ( $\gamma$-Pro), Bacteroidetes (Bact), and other bacteria for the bottom waters between stations inside (X1) and outside (X2 and X3) the hypoxic zone during the 2016 cruise. Bulk bacteria community includes FLB and PAB of $<20 \mu \mathrm{m}$. Locations of stations X1, X2, and X3 are shown in Fig. 1a. Error bars are the standard deviations.

\subsection{Particle-attached bacterial growth and metabolism in the hypoxic zone}

Incubation of the PAB acquired from the low-oxygen waters with direct additions of different doses of exogenous PUAs over $12 \mathrm{~h}$ was carried out to examine the change in bacterial growth and metabolism activities in response to PUA enrichments. At the end of the incubation experiments, BA was not different from the control for the PH treatment (Fig. 7a). However, for the PL treatment, there were substantial increases in $\mathrm{BA}$ in both the middle and the bottom waters compared to the initial conditions (Fig. 7a). In particular, BA of $\sim 3.2 \pm 0.04 \times 10^{9}$ cells $\mathrm{L}^{-1}$ in the bottom water for the PL treatment was significantly higher $(t=12.26, n=12$, $p<0.01)$ than the control of $2.5 \pm 0.07 \times 10^{9}$ cells L $^{-1}$.

BR was significantly promoted by the low-dose PUAs with a $21.6 \%$ increase in the middle layer $(t=11.91, n=8, p<$ $0.01)$ and a $25.8 \%$ increase in the bottom layer $(t=11.50$, $n=8, p<0.01)$ compared to the controls. The stimulating effect of high-dose PUAs on BR was even stronger with a $47.0 \%$ increase in the middle layer $(t=30.56, n=8, p<$ $0.01)$ and a $39.8 \%$ increase in the bottom layer $(t=9.40$, $n=8, p<0.01$ ) (Fig. 7b). Meanwhile, the cell-specific BR was significantly improved for both layers with a high dose of PUAs $(t=15.13, n=8, p<0.01$ and $t=4.77, n=8$, $p<0.01$ ) but not with a low dose of PUAs (Fig. 7c) due to the increase in BA (Fig. 7a). BGE was generally very low $(<1.5 \%)$ during all the experiments (Fig. 7d) due to substantially high rates of BR (Fig. 7b) than BP (Fig. 7e). Also, there was no significant difference in BGE between controls and PUA treatments for both layers (Fig. 7d).

For the bottom layer, BP was $12.6 \pm 0.8 \mu \mathrm{g} \mathrm{CL}^{-1} \mathrm{~d}^{-1}$ for low-dose PUAs and $16.4 \pm 0.6 \mu \mathrm{g} \mathrm{CL}^{-1} \mathrm{~d}^{-1}$ for highdose PUAs, which were both significantly $(t=2.98$, $n=8, p<0.05$ and $t=10.41, n=8, p<0.01$ ) higher than the control of $10.6 \pm 0.6 \mu \mathrm{g} \mathrm{CL}^{-1} \mathrm{~d}^{-1}$. Meanwhile, $\mathrm{BP}$ in the middle layer was significantly higher $(t=$ 2.52, $n=8, p<0.05)$ than the control for high-dose PUAs $\left(13.4 \pm 0.9 \mu \mathrm{g} \mathrm{C} \mathrm{L}^{-1} \mathrm{~d}^{-1}\right)$ but not for low-dose PUAs $\left(12.6 \pm 0.9 \mu \mathrm{g} \mathrm{CL}^{-1} \mathrm{~d}^{-1}\right)$ (Fig. 7e). The cell-specific BP values (sBP, $7.9 \pm 0.5$ and $6.9 \pm 0.2 \mathrm{fg} \mathrm{C}$ cell $^{-1} \mathrm{~d}^{-1}$ ) for high- 


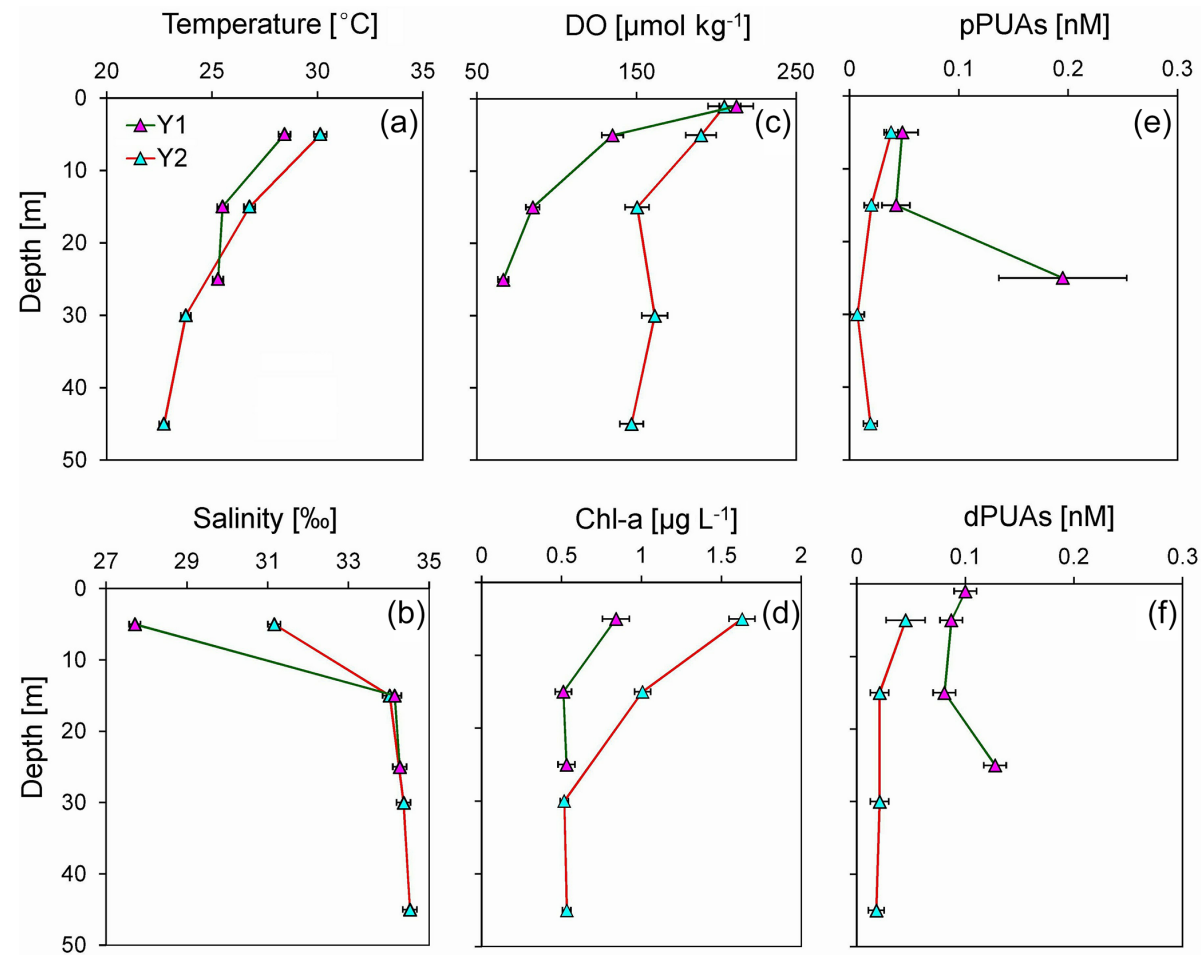

Figure 5. Vertical distributions of (a) temperature, (b) salinity, (c) dissolved oxygen (DO), (d) chlorophyll $a$ (Chl- $a$ ), (e) particulate PUAs (pPUAs), and (f) dissolved PUAs (dPUAs) inside (Y1) and outside (Y2) the hypoxic zone during June 2019. Locations of station Y1 and Y2 are shown in Fig. 1. Error bars are the standard deviations.

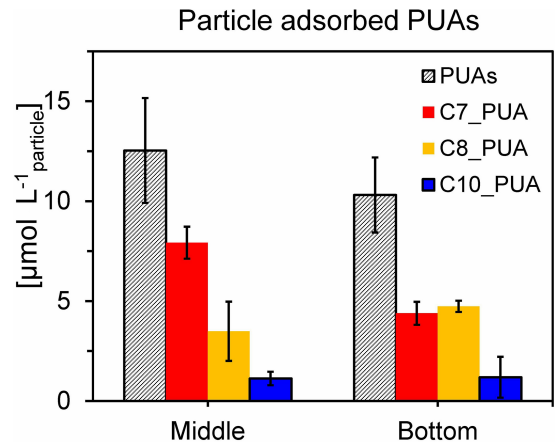

Figure 6. Concentrations of particle-adsorbed PUAs (in micromoles per liter particle) in the middle $(12 \mathrm{~m})$ and the bottom $(25 \mathrm{~m})$ waters of station Y1 during June 2019. Three different PUA components are also shown, including heptadienal (C7_PUA), octadienal (C8_PUA), and decadienal (C10_PUA). Error bars are the standard deviations.

dose PUAs were significantly $(t=2.62, n=8, p<0.05$ and $t=11.26, n=8, p<0.01$ ) higher than the control in both layers (Fig. 7f). Meanwhile, for low-dose PUAs, the sBP values in both layers were not significantly different from the controls.

\subsection{Particle-attached bacterial community change during incubations}

Generally, $\gamma$-Pro dominated ( $>68 \%$ ) the bacterial community at the class level for all experiments, followed by the second largest bacterial group of $\alpha$-Pro. There was a significant increase in $\gamma$-Pro by high-dose PUAs, with increments of $17.2 \%(t=9.25, n=8, p<0.01)$ and $19.5 \%(t=$ $6.32, n=8, p<0.01)$ for the middle and the bottom layers, respectively (Fig. 8a). However, there was no substantial change in bacterial community composition by low-dose PUAs for both layers (Fig. 8a).

On the genus level, there was also a large difference in the responses of various bacterial subgroups to the exposure of PUAs (Fig. 8b). The main contributing genus for the promotion effect by high-dose PUAs was the group of Alteromonas spp., which showed a large increase in abundance of $73.9 \%$ and $69.7 \%$ in the middle and the bottom layers. For lowdose PUAs, the promotion effect of PUAs on Alteromonas spp. was still found, although with a much lower intensity (5.4\% in the middle and $19.4 \%$ in the bottom). The promotion effect of $\gamma$-Pro by high-dose PUAs was also contributed by Halomonas spp. bacteria (percentage increase from $1.7 \%$ to $7.4 \%$ ). Meanwhile, some bacterial genus, such as Marinobacter and Methylophaga from $\gamma$-Pro, or Nautella and 

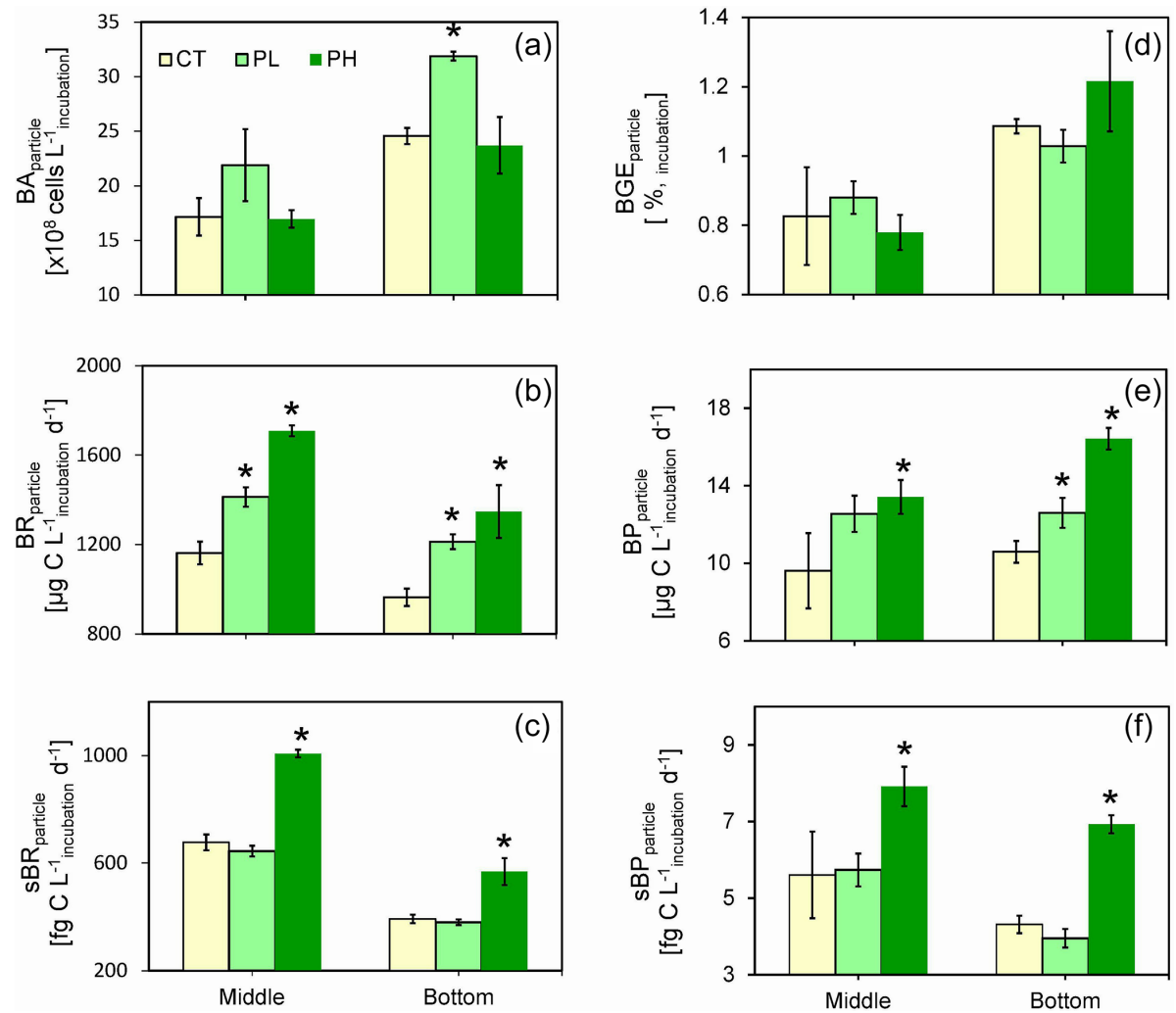

Figure 7. Responses of particle-attached bacterial parameters including (a) bacterial abundance $\left(\mathrm{BA}_{\text {particle }}\right)$, (b) bacterial respiration $\left(\mathrm{BR}_{\text {particle }}\right)$, (c) cell-specific bacterial respiration $\left(\mathrm{sBR}_{\text {particle }}\right)$, (d) bacterial growth efficiency (BGE $\left.\mathrm{Barticle}\right)$, (e) bacterial production $\left(\mathrm{BP}_{\text {particle }}\right)$, and (f) cell-specific bacterial production $\left(\mathrm{sBP}_{\text {particle }}\right)$ to different doses of PUA additions at the end of the experiments for the middle $(12 \mathrm{~m})$ and the bottom waters $(25 \mathrm{~m})$ at station Y1. Error bars are standard deviations. The star represents a significant difference $(p<0.05)$, with PL and PH the low- and high-dose PUA treatments and C the control.
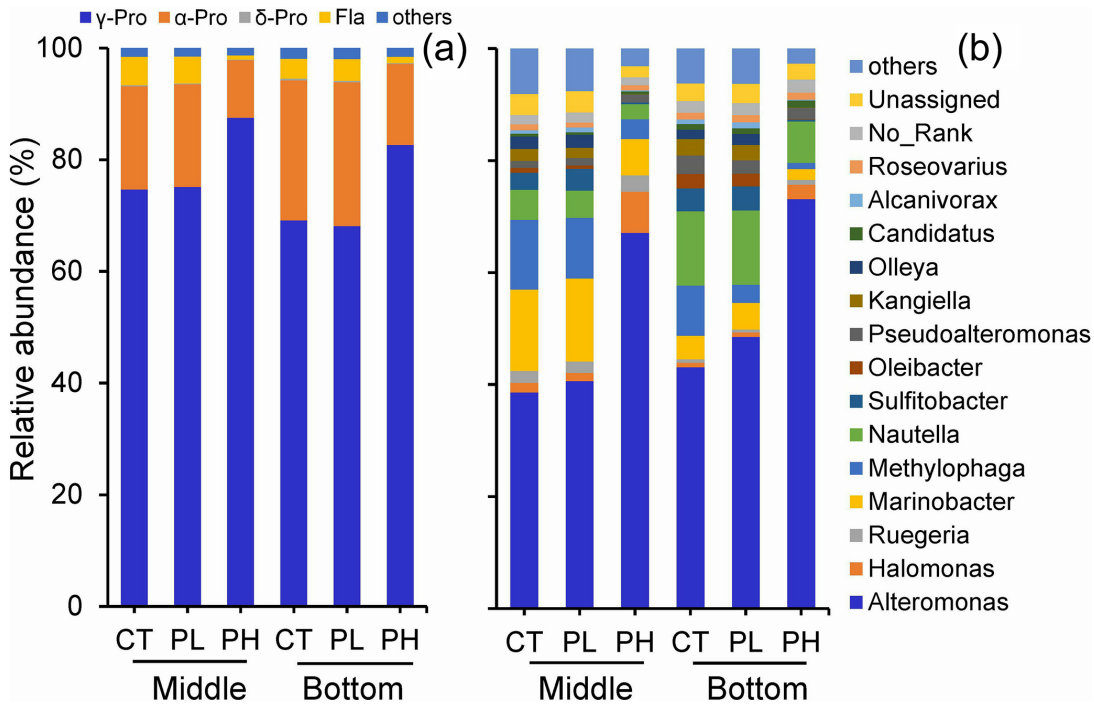

Figure 8. Variation of particle-attached bacterial community compositions on (a) the phylum level and (b) the genus level in response to different doses of PUA additions at the end of the experiments for the middle and the bottom waters at station Y1. Labels PL and PH are for the low- and high-dose PUAs with CT the control. 
Sulfitobacter from $\alpha$-Pro, showed decreased percentages by high-dose PUAs (Fig. 8b).

\subsection{Carbon-source preclusion experiments for PUAs}

After 1 month of incubation, PAB inoculated from the lowoxygen waters showed dramatic responses to both PAHs and ALKs (Fig. 9). In particular, the mediums of PAH addition became turbid brown (bottles on the left), with the medium of ALK addition turning into milky white (bottles in the middle) (Fig. 9b, d). For comparison, they were both clear and transparent at the beginning of the experiments (Fig. 9a, c). These results should reflect the growth of bacteria in these bottles with the enrichments of organic carbons. Meanwhile, the minimal medium with the addition of heptadienal (C7_PUA) remained clear and transparent as it was originally, which would indicate that $\mathrm{PAB}$ did not grow in the treatment of C7_PUA.

\section{Discussion}

Hypoxia occurs if the rate of oxygen consumption exceeds that of oxygen replenishment by diffusion, mixing, and advection (Rabouille et al., 2008). The spatial mismatch between the surface chlorophyll- $a$ maxima and the subsurface hypoxia during our estuary-to-shelf transect should indicate that the low-oxygen feature may not be directly connected to particle export by the surface phytoplankton bloom. This outcome can be a combined result of riverine nutrient input in the surface, water-column stability driven by wind and buoyancy forcing, and flow convergence for an accumulation of organic matter in the bottom (Lu et al., 2018).

Elevated concentrations of pPUAs and dPUAs near the bottom boundary of the salt wedge should reflect a sediment source of PUAs, as the surface phytoplankton above them was very low. PUA precursors such as PUFAs could be accumulated as detritus in the surface sediment near the PRE mouth during the spring blooms (Hu et al., 2006). Strong convergence at the bottom of the salt wedge could be driven by shear vorticity and topography (Lu et al., 2018). This would allow for the resuspension of small detrital particles. Improved PUA production by oxidation of the resuspended PUFAs could occur below the salt wedge as a result of enhanced lipoxygenase activity (in the resuspended organic detritus) in response to the salinity increase by the intruded bottom seawater (Galeron et al., 2018).

Direct measurement of the adsorbed PUA concentration associated with the suspended particles of $>25 \mu \mathrm{m}$ by the method of combined large-volume filtration and on-site derivation and extraction yields a high level of $\sim 10 \mu \mathrm{mol} \mathrm{L}^{-1}$ within the hypoxic zone. This value is comparable to those previously reported in sinking particles $(>50 \mu \mathrm{m})$ of the open ocean using the particle volume calculated from diatom-derived marine-snow particles (Edward et al., 2015). Note that there was also a higher level of $240 \mu \mathrm{mol} \mathrm{L}^{-1}$ found in another station outside the PRE. A micromolar level of particle-adsorbed PUAs could act as a hotspot for bacteria, likely exerting important impacts as signaling molecules on microbial utilization of particulate organic matter and subsequent oxygen consumption.

It should be mentioned that various pore sizes have been used for PAB sampling in the literature. A $0.8 \mu \mathrm{m}$ filtration was generally accepted for separating PAB $(>0.8 \mu \mathrm{m})$ and FLB $(0.2-0.8 \mu \mathrm{m})$ in the ocean (Robinson and Williams, 2005; Kirchman, 2008; Huang et al., 2018; Liu et al., 2020). Other studies defined a size of $>3 \mu \mathrm{m}$ for PAB and $0.2-3 \mu \mathrm{m}$ for FLB in some coastal waters (Crump et al. 1998; Garneau et al., 2009; Zhang et al., 2016). Meanwhile, there were also many studies using much larger sizes of filtration for PAB: a $5 \mu \mathrm{m}$ filter in the German Wadden Sea (Rink et al., 2003), a $10 \mu \mathrm{m}$ filter in the Santa Barbara Channel (DeLong et al., 1993), a $30 \mu \mathrm{m}$ filter in the Black Sea (Fuchsman et al., 2011), and a $50 \mu \mathrm{m}$ mesh nylon net in the North Atlantic waters (Edwards et al., 2015).

The hypoxic waters below the salt wedge have high turbidity probably due to particle resuspension. High particle concentration here may explain the previous finding of a higher abundance of PAB than FLB in the same area (e.g., Li et al., 2018; Liu et al., 2020), similar to those found in the Columbia River estuary (Crump et al., 1998). Also, anaerobic bacteria and taxa preferring low-oxygen conditions were found more enriched in the particle-attached communities than their free-living counterparts in the PRE (Zhang et al., 2016). Our field measurements suggested that bacterial respiration within the hypoxic waters was largely contributed by PAB $(>0.8 \mu \mathrm{m})$, with FLB $(0.2-0.8 \mu \mathrm{m})$ playing a relatively small role. Therefore, it is crucial to address the linkage between the high-density PAB and the high level of particleadsorbed PUAs associated with the suspended particles in the low-oxygen waters.

We choose a larger pore size of $25 \mu \mathrm{m}$ for collecting bacteria attached to sinking aggregates and large suspended particles. Firstly, it has been suggested that the microbial respiration rate can be positively related to aggregate size (Ploug et al., 2002), and thus larger PAB likely contributes more to oxygen consumption. Secondly, larger particle size can better present the PAB taxonomy according to the previous finding of the saturation of species accumulation (for the sizefractionated bacteria) when the size is greater than $20 \mu \mathrm{m}$ (Mestre et al., 2017). Thus, the taxonomic groups of PAB caught on particles of $>25 \mu \mathrm{m}$ should already cover those of PAB on smaller particles of $0.8-25 \mu \mathrm{m}$. A similar type of filtration $(30 \mu \mathrm{m})$ has been previously applied to study PAB in the Black Sea suboxic zones (Fuchsman et al., 2011).

Interestingly, our PUA-amended experiments for PAB $(>25 \mu \mathrm{m})$ retrieved from the low-oxygen waters revealed distinct responses of PAB to different doses of PUA treatments with an increase in cell growth in response to low-dose PUAs $\left(1 \mu \mathrm{mol} \mathrm{L}^{-1}\right)$ but an elevated cell-specific metabolic 


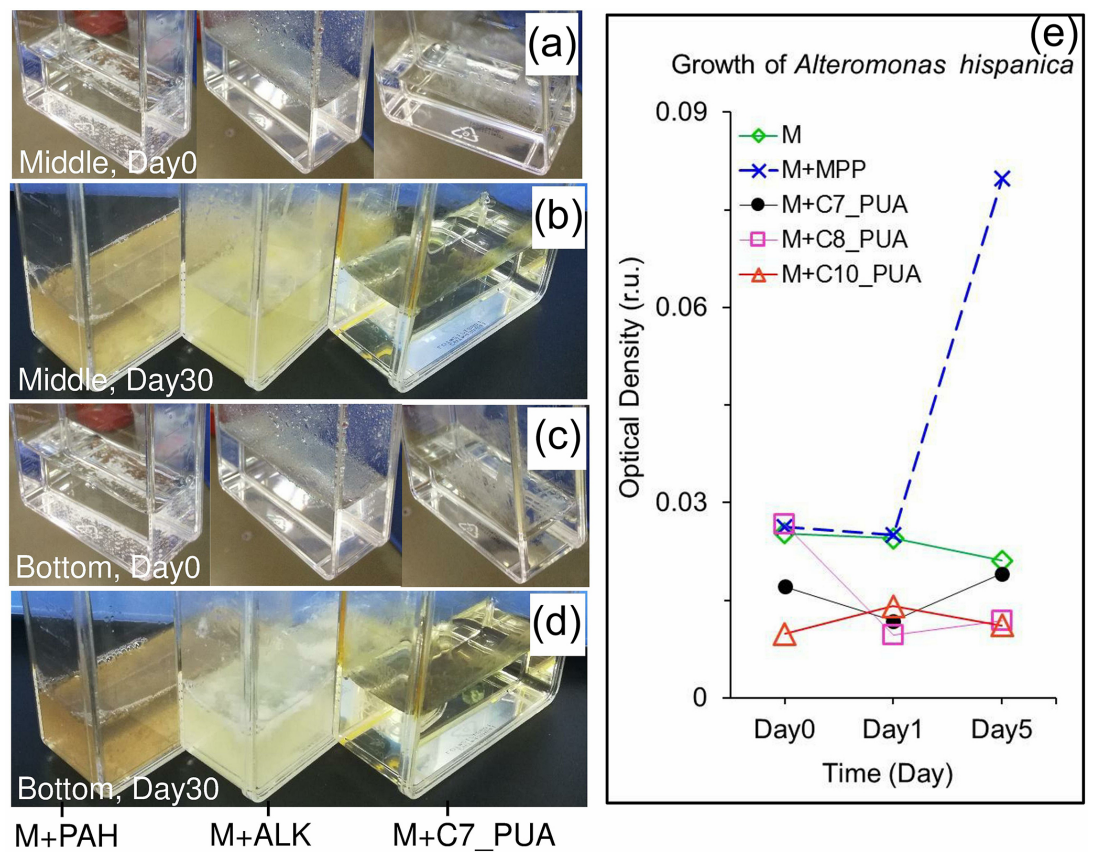

Figure 9. Carbon-source test of PUAs with cell culture of particle-attached bacteria inoculated from the low-oxygen waters of station Y1 including the initial conditions (day 0) at the beginning of the experiments as well as results after 30 d of incubations (day 30) for $(\mathbf{a}, \mathbf{b})$ the middle and $(\mathbf{c}, \mathbf{d})$ the bottom waters, respectively. Bottles from left to right are the mediums (M) with the additions of polycyclic aromatic hydrocarbons $(\mathrm{M}+\mathrm{PAH}, 200 \mathrm{ppm})$, alkanes $\left(\mathrm{M}+\mathrm{ALK}, 0.25 \mathrm{~g} \mathrm{~L}^{-1}\right)$, and heptadienal $\left(\mathrm{M}+\mathrm{C} 7 \_\mathrm{PUA}, 0.2 \mathrm{mmol} \mathrm{L}-1\right)$; note that a change in turbidity should indicate bacterial utilization of organic carbons. (e) The optical density of bacterium Alteromonas hispanica MOLA151 growing in the minimal medium as well as in the mediums with the additions of mannitol, pyruvate, and proline (M + MPP, $1 \%$ each), heptadienal $\left(\mathrm{M}+\mathrm{C} 7 \_\mathrm{PUA}, 145 \mu \mathrm{M}\right)$, octadienal $\left(\mathrm{M}+\mathrm{C} 8 \_\mathrm{PUA}, 130 \mu \mathrm{M}\right)$, and decadienal $\left(\mathrm{M}+\mathrm{C} 10 \_\mathrm{PUA}, 106 \mu \mathrm{M}\right)$. The method for A. hispanica growth and the data in panel (e) are from Ribalet et al. (2008).

activity including bacterial respiration and production in response to high-dose PUAs $\left(100 \mu \mathrm{mol} \mathrm{L}^{-1}\right)$. An increase in cell density of PAB by low-dose PUAs could likely reflect the stimulating effect of PUAs on PAB growth. This finding was consistent with the previous report of a PUAs level of 0 $10 \mu \mathrm{mol} \mathrm{L}^{-1}$ stimulating respiration and cell growth of PAB in sinking particles of the open ocean (Edwards et al., 2015). The negligible effect of low-dose PUAs on bacterial community structure in our experiments was also in good agreement with those found for PAB from sinking particles (Edwards et al., 2015). However, we do not see the inhibitory effect of $100 \mu \mathrm{mol} \mathrm{L}^{-1}$ PUAs on PAB respiration and production previously found in the open ocean (Edward et al., 2015). Instead, the stimulating effect for high-dose PUAs on bacterial respiration and production was even stronger with $\sim 50 \%$ increments. The bioactivity of PUAs on bacterial strains could likely arise from their specific arrangement of two double bonds and carbonyl chain (Ribalet et al., 2008). Our findings support the important role of PUAs in enhancing bacterial oxygen utilization in low-oxygen waters.

It should be mentioned that the effect of background nanomolar PUAs on free-living bacteria remains controversial, which is not our focus in this study. Previous studies suggested that $7.5 \mathrm{nmol} \mathrm{L}^{-1}$ of PUAs would have a different effect on the metabolic activities of distinct bacterial groups in the NW Mediterranean Sea, although bulk bacterial abundance remained unchanged (Balestra et al., 2011). In particular, the metabolic activity of $\gamma$-Pro was least affected by nanomolar PUAs, although those of Bacteroidetes and Rhodobacteraceae were markedly depressed (Balestra et al., 2011). Meanwhile, the daily addition of $1 \mathrm{nmol} \mathrm{L}^{-1}$ PUAs was found to not affect the bacterial abundance and community composition during a mesocosm experiment in the Bothnian Sea (Paul et al., 2012).

It is important to verify that the PUAs are not an organic carbon source but a stimulator for PAB growth and metabolism. This was supported by the fact that the inoculated PAB could not grow in the medium with $200 \mu \mathrm{mol} \mathrm{L}^{-1}$ of PUAs although they grew pretty well in the mediums with a similar amount of ALKs or PAHs. Our results support the previous findings that the density of Alteromonas hispanica was not significantly affected by $100 \mu \mathrm{mol} \mathrm{L}^{-1}$ of PUAs in the minimal medium (without any organic carbons) during laboratory experiments (Fig. 9e), where PUAs were considered to act as cofactors for bacterial growth (Ribalet et al., 2008).

Improved cell-specific metabolism of $\mathrm{PAB}$ in response to high-dose PUAs was accompanied by a significant shift of 
bacterial community structure. The group of PAB with the greatest positive responses to exogenous PUAs was the genus Alteromonas within the $\gamma$-Pro, which is well known to have a particle-attached lifestyle with rapid growth response to organic matter (Ivars-Martinez et al., 2008). This result is contradicted by the previous finding of a reduced percentage of the $\gamma$-Pro class by high-dose PUAs in the PAB of open ocean sinking particles (Edward et al., 2015). Meanwhile, previous studies suggested that different genus groups within the $\gamma$ Pro may respond distinctly to PUAs (Ribalet et al., 2008). Our result was well consistent with the previous finding of the significant promotion effect of 13 or $106 \mu \mathrm{mol} \mathrm{L}^{-1}$ PUAs on Alteromonas hispanica from the pure culture experiment (Ribalet et al., 2008). An increase in PUAs could thus confer on some of the $\gamma$-Pro (mainly special species within the genus Alteromonas, such as A. hispanica, Fig. S2b) a competitive advantage over other bacteria, leading to their population dominance on particles in the low-oxygen waters. These results provide evidence for a previous hypothesis that PUAs could shape the bacterioplankton community composition by driving the metabolic activity of bacteria with neutral, positive, or negative responses (Balestra et al., 2011).

The taxonomic composition of PAB $(>25 \mu \mathrm{m})$ was substantially different from that of the bulk bacteria community in the hypoxic zone (with a large increase in $\gamma$-Pro associated with particles, Fig. S2a). This result supports the previous report of $\gamma$-Pro being the most dominant clade attached to sinking particles in the ocean (DeLong et al., 1993). A broad range of species associated with $\gamma$-Pro was known to be important for quorum-sensing processes due to their high population density (Doberva et al., 2015) associated with sinking or suspended aggregates (Krupke et al., 2016). In particular, the genera of $\gamma$-Pro such as Alteromonas and Pseudomonas are well-known quorum-sensing bacteria that can rely on diverse signaling molecules to affect particle-associated bacterial communities by coordinating gene expression within the bacterial populations (Long et al., 2003; Fletcher et al., 2007).

It has been reported that the growths of some bacterial strains of the $\gamma$-Pro such as Alteromonas spp. and Pseudomonas spp. could be stimulated and regulated by oxylipins like PUAs (Ribalet et al., 2008; Pepi et al., 2017). Oxylipins were found to promote biofilm formation of Pseudomonas spp. (Martinez et al., 2016) and could serve as signaling molecules mediating cell-to-cell communication of Pseudomonas spp. by an oxylipin-dependent quorum-sensing system (Martinez et al., 2019). As PUAs are an important group of chemical cues belonging to oxylipins (Franzè et al., 2018), it is thus reasonable to expect that PUAs may also participate as potential signaling molecules for the quorum sensing among a high-density Alteromonas or Pseudomonas. A high level of particle-adsorbed PUAs occurring on organic particles in the low-oxygen water would likely allow particle specialists such as Alteromonas to regulate bacterial community structure, which could alter species richness and di- versity of PAB as well as their metabolic functions such as respiration and production when interacting with particulate organic matter in the hypoxic zone. Various bacterial assemblages may have different rates and efficiencies of particulate organic matter degradation (Ebrahimi et al., 2019). Coordination amongst these PAB could be critical in their ability to thrive on the recycling of particulate organic carbon (Krupke et al., 2016) and thus likely contribute to the acceleration of oxygen utilizations in the hypoxic zone. Nevertheless, the molecular mechanism of the potential PUA-dependent quorum sensing of PAB may be an important topic for future study.

Our findings may likely apply to other coastal systems where there are large river inputs, intense phytoplankton blooms driven by eutrophication, and strong hypoxia, such as the Chesapeake Bay, the Adriatic Sea, and the Baltic Sea. For example, the Chesapeake Bay is largely influenced by river runoff with strong eutrophication-driven hypoxia during the summer as a result of increased water stratification (Fennel and Testa, 2019) and enhanced microbial respiration fueled by organic carbons produced during spring diatom blooms (Harding et al., 2015). Similar to the PRE, there was also a high abundance of $\gamma$-Pro in the low-oxygen waters of the Chesapeake Bay associated with the respiration of resuspended organic carbon (Crump et al., 2007). Eutrophication causes intense phytoplankton blooms in the coastal ocean. Sedimentation of the phytoplankton carbons will lead to their accumulation in the surficial sediment (Cloern, 2001), including PUFA compounds derived from the lipid production. Resuspension and oxidation of these PUFA-rich organic particles during summer salt-wedge intrusion might lead to high particle-adsorbed PUAs in the water column. These PUAs could likely shift the particle-attached bacterial community to consume more oxygen when degrading particulate organic matter and thus potentially contribute to the formation of seasonal hypoxia. In this sense, the possible role of PUAs on coastal hypoxia may be a byproduct of eutrophication driven by anthropogenic nutrient loading. Further studies are required to quantify the contributions from PUA-mediated oxygen loss by aerobic respiration to total deoxygenation in the coastal ocean.

\section{Conclusions}

In summary, we found elevated concentrations of pPUAs and dPUAs in the hypoxic waters below the salt wedge. We also found high particle-adsorbed PUAs associated with particles of $>25 \mu \mathrm{m}$ in the hypoxic waters based on the large-volume filtration method, which could generate a hotspot PUA concentration of $>10 \mu \mathrm{mol} \mathrm{L}^{-1}$ in the water column. In the hypoxic waters, bacterial respiration was largely controlled by PAB $(>0.8 \mu \mathrm{m})$, with FLB $(0.2-0.8 \mu \mathrm{m})$ only accounting for $25 \%-30 \%$ of the total respiration. Field PUA-amended experiments were conducted for $\mathrm{PAB}$ associated with particles 
of $>25 \mu \mathrm{m}$ retrieved from the low-oxygen waters. We found distinct responses of PAB $(>25 \mu \mathrm{m})$ to different doses of PUA treatments with an increase in cell growth in response to low-dose PUAs $\left(1 \mu \mathrm{mol} \mathrm{L}{ }^{-1}\right)$ but an elevated cell-specific metabolic activity including bacterial respiration and production in response to high-dose PUAs $\left(100 \mu \mathrm{mol} \mathrm{L}^{-1}\right)$. Improved cell-specific metabolism of PAB in response to highdose PUAs was also accompanied by a substantial shift of bacterial community structure with increased dominance of the genus Alteromonas within the $\gamma$-Pro.

Based on these observations, we hypothesize that PUAs may potentially act as signaling molecules for coordination among the high-density PAB below the salt wedge, which would likely allow bacteria such as Alteromonas to thrive in degrading particulate organic matter. Very possibly, this process by changing community compositions and metabolic rates of PAB would lead to an increase in microbial oxygen utilization that might eventually contribute to the formation of coastal hypoxia.

Code availability. No special software codes were generated or used during the study.

Data availability. Some of the data used in the present study are available in the Supplement. Other data analyzed in this article are tabulated herein. Any additional data can be requested from the corresponding author.

Supplement. The supplement related to this article is available online at: https://doi.org/10.5194/bg-18-1049-2021-supplement.

Author contributions. QPL designed the project. ZW performed the experiments. QPL and ZW wrote the paper with inputs from all co-authors. All authors have approved the final version of the paper.

Competing interests. The authors declare that they have no conflict of interest.

Acknowledgements. We are grateful to the captains and the staff of R/V Haike 68 and R/V Tan Kah Kee for their help during the cruises. We thank Dongxiao Wang (SCSIO) and Xin Liu (XMU) for organizing the cruises, Yuchen Zhang (XMU) for field assistance, Changsheng Zhang (SCSIO) and Weimin Zhang (GIM) for analytical assistance, and Dennis Hansell (RSMAS) for critical comments.

Financial support. This research has been supported by the National Natural Science Foundation of China (grant no. 41706181 and 41676108), the National Key Research and Development Program of China (grant no. 2016YFA0601203), the Key Special
Project for Introduced Talents Team of Southern Marine Science and Engineering Guangdong Laboratory (Guangzhou) (grant no. GML2019ZD0305), the Guangdong Province Special Support Plan for Leading Talents (grant no. 2019TX05H216), and the Visiting Fellowship Program (MELRS1936) of the State Key Laboratory of Marine Environmental Science (Xiamen University).

Review statement. This paper was edited by Tyler Cyronak and reviewed by two anonymous referees.

\section{References}

Balestra, C., Alonso-Saez, L., Gasol, J. M., and Casotti, R.: Groupspecific effects on coastal bacterioplankton of polyunsaturated aldehydes produced by diatoms, Aquat. Microb. Ecol., 63, 123131, https://doi.org/10.3354/ame01486, 2011.

Bartual, A., Morillo-Garcia, S., Ortega, M. J., and Cozar, A.: First report on vertical distribution of dissolved polyunsaturated aldehydes in marine coastal waters, Mar. Chem., 204, 1-10, https://doi.org/10.1016/j.marchem.2018.05.004, 2018.

Breitburg, D., Levin, L. A., Oschlies, A., Gregoire, M., Chavez, F. P., Conley, D. J., Garcon, V., Gilbert, D., Gutierrez, D., Isensee, K., Jacinto, G. S., Limburg, K. E., Montes, I., Naqvi, S. W. A., Pitcher, G. C., Rabalais, N. N., Roman, M. R., Rose, K. A., Seibel, B. A., Telszewski, M., Yasuhara, M., and Zhang, J.: Declining oxygen in the global ocean and coastal waters, Science, 359, eaam7240, https://doi.org/10.1126/science.aam7240, 2018.

Cloern, J. E.: Our evolving conceptual model of the coastal eutrophication problem, Mar. Ecol. Prog. Ser., 210, 223-253, https://doi.org/10.3354/meps210223, 2001.

Crump, B. C., Baross, J. A., and Simenstad, C. A.: Dominance of particle-attached bacteria in the Columbia River estuary, USA. Aquat. Microb. Ecol., 14, 7-18, https://doi.org/10.3354/ ame014007, 1998.

Crump, B. C., Peranteau, C., Beckingham, B., and Cornwell J. C.: Respiratory succession and community succession of bacterioplankton in seasonally anoxic estuarine waters, Appl. Environ. Microb., 73, 6802-6810, https://doi.org/10.1128/aem.00648-07, 2007.

Decho, A. W., Visscher, P. T., Ferry, J., Kawaguchi, T., He, L., Przekop, K. M., Norman, R. S., and Reid, R. P.: Autoinducers extracted from microbial mats reveal a surprising diversity of N-acylhomoserine lactones (AHLs) and abundance changes that may relate to diel pH, Environ. Microb., 11, 409-420, https://doi.org/10.1111/j.1462-2920.2008.01780.x, 2009.

Delong, E. F., Franks, D. G., and Alldredge, A. L.: Phylogenetic diversity of aggregate-attached vs free-living marine bacterial assemblages, Limnol. Oceanogr., 38, 924-934, https://doi.org/10.4319/lo.1993.38.5.0924, 1993.

Diaz, R. J. and Rosenberg, R.: Spreading dead zones and consequences for marine ecosystems, Science, 321, 926-929, https://doi.org/10.1126/science.1156401, 2008.

Doberva, M., Sanchez-Ferandin, S., Toulza, E., Lebaron P., and Lami, R.: Diversity of quorum sensing autoinducer synthases in the Global Ocean Sampling metagenomic database, Aquat. Microb. Ecol., 74, 107-119, https://doi.org/10.3354/ame01734, 2015. 
Doney, S. C., Ruckelshaus, M., Duffy, J. E., Barry, J. P., Chan, F., English, C. A., Galindo, H. M., Grebmeier, J. M., Hollowed, A. B., Knowlton, N., Polovina, J., Rabalais, N. N., Sydeman, W. J., and Talley, L. D.: Climate change impacts on marine ecosystems, Annu. Rev. Mar. Sci., 4, 11-37, https://doi.org/10.1146/annurevmarine-041911-111611, 2012.

Dyksterhouse, S. E., Gray, J. P., Herwig, R. P., Lara, J. C., and Staley, J. T.: Cycloclasticus pugetii gen. nov., sp. nov., an aromatic hydrocarbon-degrading bacterium from marine sediments, Int. J. of Syst. Bacteriol., 45, 116-123, https://doi.org/10.1099/00207713-45-1-116, 1995.

Edwards, B. R., Bidle, K. D., and van Mooy, B. A. S.: Dose-dependent regulation of microbial activity on sinking particles by polyunsaturated aldehydes: implications for the carbon cycle, P. Natl. Acad. Sci. USA, 112, 5909-5914, https://doi.org/10.1073/pnas.1422664112, 2015.

Ebrahimi, A., Schwartzman, J., and Cordero, O. X.: Cooperation and self-organization determine rate and efficiency of particulate organic matter degradation in marine bacteria, P. Natl. Acad. Sci. USA, 116, 23309-23316, https://doi.org/10.1073/pnas.1908512116, 2019.

Fennel, K. and Testa, J. M.: Biogeochemical Controls on Coastal Hypoxia, Annu. Rev. Mar. Sci., 11, 1-26, https://doi.org/10.1146/annurev-marine-010318-095138, 2019.

Fletcher, M. P., Diggle, S. P., Crusz, S. A., Chhabra, S. R., Camara, M., and Williams, P.: A dual biosensor for 2-alkyl-4-quinolone quorum-sensing signal molecules, Environ. Microbiol., 9, $2683-$ 2693, https://doi.org/10.1111/j.1462-2920.2007.01380.x, 2007.

Franzè, G., Pierson, J. J., Stoecker, D. K., and Lavrentyev, P. J.: Diatom-produced allelochemicals trigger trophic cascades in the planktonic food web, Limnol. Oceanogr., 63, 1093-1108, https://doi.org/10.1002/lno.10756, 2018.

Fuchsman, C. A., Kirkpatrick, J. B., Brazelton, W. J., Murray, J. W., and Staley, J. T.: Metabolic strategies of free-living and aggregate-associated bacterial communities inferred from biologic and chemical profiles in the Black Sea suboxic zone, FEMS Microbiol. Ecol., 78, 586-603, https://doi.org/10.1111/j.15746941.2011.01189.x, 2011.

Galeron, M. A., Radakovitch, O., Charriere, B., Vaultier, F., Volkman, J. K., Bianchi, T. S., Ward, N. D., Medeiros, P. M., Sawakuchi, H. O., Tank, S., Kerherve, P., and Rontani, J. F.: Lipoxygenase-induced autoxidative degradation of terrestrial particulate organic matter in estuaries: A widespread process enhanced at high and low latitude, Org. Geochem., 115, 78-92, https://doi.org/10.1016/j.orggeochem.2017.10.013, 2018.

García-Martín, E. E., Aranguren-Gassis, M., Karl, D. M., MartínezGarcía, S., Robinson, C., Serret, P., and Teira, E.: Validation of the in vivo Iodo-Nitro-Tetrazolium (INT) salt reduction method as a proxy for plankton respiration. Front. Mar. Sci., 6, 220, https://doi.org/10.3389/fmars.2019.00220, 2019.

Garneau, M. E., Vincent, W. F., Terrado, R., and Lovejoy, C.: Importance of particle-associated bacterial heterotrophy in a coastal Arctic ecosystem, J. Mar. Syst., 75, 185-197, https://doi.org/10.1016/j.jmarsys.2008.09.002, 2009.

Ge, Z., Wu, Z., Liu Z., Zhou, W., Dong, Y., and Li, Q. P.: Using detaching method to determine the abundance of particle-attached bacteria from the Pearl River Estuary and its coupling relationship with environmental factors, Chinese J. Mar. Environ. Sci., 4, 505-510, https://doi.org/10.12111/j.mes.20190065, 2020.
Harding Jr., L. W., Adolf, J. E., Mallonee, M. E., Miller, W. D., Gallegos, C. L., Perry, E. S., Johnson, J. M., Sellner, K. G., and Paerl, H. W.: Climate effects on phytoplankton floral composition in Chesapeake Bay, Estuar. Coast. Shelf S., 162, 53-68, https://doi.org/10.1016/j.ecss.2014.12.030, 2015.

He, B. Dai, M., Zhai, W., Guo, X., and Wang, L.: Hypoxia in the upper reaches of the Pearl River Estuary and its maintenance mechanisms: A synthesis based on multiple year observations during 2000-2008, Mar. Chem., 167, 13-24, https://doi.org/10.1016/j.marchem.2014.07.003, 2014.

Hopkinson, C. S.: Shallow-water benthic and pelagic metabolismevidence of heterotrophy in the nearshore Geogia bight, Mar. Biol., 87, 19-32, https://doi.org/10.1007/bf00397002, 1985.

Helm, K. P., Bindoff, N. L., and Church, J. A.: Observed decreases in oxygen content of the global ocean, Geophys. Res. Lett., 38, L23602, https://doi.org/10.1029/2011GL049513, 2011.

Hmelo, L. R., Mincer, T. J., and Van Mooy, B. A. S.: Possible influence of bacterial quorum sensing on the hydrolysis of sinking particulate organic carbon in marine environments, Environ. Microb. Rep., 3, 682-688, https://doi.org/10.1111/j.1758 2229.2011.00281.x, 2011.

Huang, Y., Liu, X., Laws, E. A., Chen, B., Li, Y., Xie, Y., Wu, Y., Gao, K., and Huang, B.: Effects of increasing atmospheric $\mathrm{CO}_{2}$ on the marine phytoplankton and bacterial metabolism during a bloom: A coastal mesocosm study, Sci. Total Environ., 633, 618629, https://doi.org/10.1016/j.scitotenv.2018.03.222, 2018.

$\mathrm{Hu}$, J., Zhang H., and Peng P.: Fatty acid composition of surface sediments in the subtropical Pearl River estuary and adjacent shelf, Southern China, Estuar. Coast, Shelf S., 66, 346-356, https://doi.org/10.1016/j.ecss.2005.09.009, 2006.

Ianora, A. and Miralto, A.: Toxigenic effects of diatoms on grazers, phytoplankton and other microbes: a review, Ecotoxicology, 19, 493-511, https://doi.org/10.1007/s10646-009-0434-y, 2010.

Ivars-Martinez, E., Martin-Cuadrado, A. B., D’Auria, G., Mira, A., Ferriera, S., Johnson, J., Friedman, R., and Rodriguez-Valera F.: Comparative genomics of two ecotypes of the marine planktonic copiotroph Alteromonas macleodii suggests alternative lifestyles associated with different kinds of particulate organic matter, ISME J., 2, 1194-1212, 2008.

Kemp, W. M., Testa, J. M., Conley, D. J., Gilbert, D., and Hagy, J. D.: Temporal responses of coastal hypoxia to nutrient loading and physical controls, Biogeosciences, 6, 2985-3008, https://doi.org/10.5194/bg-6-2985-2009, 2009.

Krupke, A., Hmelo, L. R., Ossolinski, J. E., Mincer, T. J., and Van Mooy, B. A. S.: Quorum sensing plays a complex role in regulating the enzyme hydrolysis activity of microbes associated with sinking particles in the ocean, Front. Mar. Sci., 3, 55, https://doi.org/10.3389/fmars. 2016.00055, 2016.

Kirchman, D. L.: Leucine incorporation as a measure of biomass production by heterotrophic bacteria, in: Hand book of methods in aquatic microbial ecology, edited by: Kemp, P. F., Cole, J. J., Sherr, B. F., and Sherr, E. B., Lewis Publishers, Boca Raton, 509512, https://doi.org/10.1201/9780203752746-59, 1993.

Kirchman, D. L.: Microbial ecology of the oceans, 2 Edn., Hoboken, New Jessy, Wiley, 1-593, https://doi.org/10.1002/9780470281840, 2008.

Lee, S., Lee, C., Bong, C., Narayanan, K., and Sim, E.: The dynamics of attached and free-living bacterial population in 
tropical coastal waters, Mar. Freshwater Res., 66, 701-710, https://doi.org/10.1071/mf14123, 2015.

Li, J., Salam, N., Wang, P., Chen L., Jiao, J., Li, X., Xian, W., Han, M., Fang, B., Mou, X., and Li, W.: Discordance between resident and active bacterioplankton in free-living and particle-associated communities in estuary ecosystem. Microb. Ecol., 76, 637-647, https://doi.org/10.1007/s00248-018-1174-4, 2018

Liu, Y., Lin, Q., Feng, J., Yang, F., Du, H., Hu, Z., and Wang, H.: Differences in metabolic potential between particle-associated and free-living bacteria along Pearl River Estuary, Sci. Total Environ., 728, 138856, https://doi.org/10.1016/j.scitotenv.2020.138856, 2020

Long, R. A., Qureshi, A., Faulkner, D. J., and Azam, F.: 2-npentyl-4-quinolinol produced by a marine Alteromonas sp and its potential ecological and biogeochemical roles, Appl. Environ. Microb., 69, 568-576, https://doi.org/10.1128/aem.69.1.568576.2003, 2003.

Lu, Z., Gan, J., Dai, M., Liu, H., and Zhao, X.: Joint effects of extrinsic biophysical fluxes and intrinsic hydrodynamics on the formation of hypoxia west off the Pearl River Estuary, J. Geophys. Res.-Oceans., 123, 6241-6259. https://doi.org/10.1029/2018JC014199, 2018.

Lunau, M., Lemke, A., Walther, K., Martens-Habbena, W., and Simon, M.: An improved method for counting bacteria from sediments and turbid environments by epifluorescence microscopy, Environ. Microbiol., 7, 961-968, https://doi.org/10.1111/j.14622920.2005.00767.x, 2005.

Marie, D., Partensky, F., Jacquet, S., and Vaulot, D.: Enumeration and cell cycle analysis of natural populations of marine picoplankton by flow cytometry using the nucleic acid stain SYBR Green I, Appl. Environ. Microbiol., 63, 186-193, https://doi.org/10.1128/AEM.63.1.186-193.1997, 1997.

Martinez, E. and Campos-Gomez, J.: Oxylipins produced by Pseudomonas aeruginosa promote biofilm formation and virulence, Nat. Commun., 7, 13823, https://doi.org/10.1038/ncomms13823, 2016.

Martinez, E., Cosnahan, R. K., Wu, M. S., Gadila, S. K., Quick, E. B., Mobley, J. A., and Campos-Gomez, J.: Oxylipins mediate cell-to-cell communication in Pseudomonas aeruginosa, Commun. Biol., 2, 66, https://doi.org/10.1038/s42003-019-0310-0, 2019.

Mestre, M., Borrull, E., Sala, M. M., and Gasol, J. M.: Patterns of bacterial diversity in the marine planktonic particulate matter continuum, ISME J., 11, 999-1010, https://doi.org/10.1038/ismej.2016.166, 2017.

Oudot, C., Gerard, R., Morin, P., and Gningue, I.: Precise shipboard determination of dissolved-oxygen (winkler procedure) for productivity studies with a commercial system, Limnol. Oceanogr., 33, 146-150, https://doi.org/10.4319/lo.1988.33.1.0146, 1988.

Parsons, T. R., Maita, Y., and Lalli, C. M.: Fluorometric Determination of Chlorophylls, in: A manual of chemical and biological methods for seawater analysis, Pergamum Press, Oxford, 107-109, https://doi.org/10.1016/B978-0-08-030287-4.50034-7, 1984.

Paul, C., Reunamo, A., Lindehoff, E., Bergkvist, J., Mausz, M. A., Larsson, H., Richter, H., Wangberg, S., Leskinen, P., Bamstedt, U., and Pohnert, G.: Diatom derived polyunsaturated aldehydes do not structure the planktonic microbial community in a mesocosm study, Mar. Drugs, 10, 775-792, https://doi.org/10.3390/md10040775, 2012.

Pepi, M., Heipieper, H. J., Balestra, C., Borra, M., Biffali, E., and Casotti, R.: Toxicity of diatom polyunsaturated aldehydes to marine bacterial isolates reveals their mode of action, Chemosphere, 177, 258-265, 2017

Ploug, H., Zimmermann-Timm, H., and Schweitzer, B.: Microbial communities and respiration on aggregates in the Elbe Estuary, Germany, Aquat. Microb. Ecol., 27, 241-248, 2002

Pohnert, G.: Wound-activated chemical defense in unicellular planktonic algae, Ange. Chem. Int Edit., 39, 4352-4354, https://doi.org/10.1002/15213773(20001201)39:23<4352::AID-ANIE4352>3.0.CO;2-U, 2000.

Rabouille, C., Conley, D. J., Dai, M. H., Cai, W. J., Chen, C. T. A., Lansard, B., Green, R., Yin, K., Harrison, P. J., Dagg, M., and McKee, B.: Comparison of hypoxia among four riverdominated ocean margins: The Changjiang (Yangtze), Mississippi, Pearl, and Rhone rivers, Cont. Shelf Res., 28, 1527-1537, https://doi.org/10.1016/j.csr.2008.01.020, 2008.

Ribalet, F., Intertaglia, L., Lebaron, P., and Casotti, R.: Differential effect of three polyunsaturated aldehydes on marine bacterial isolates, Aquat. Toxicol., 86, 249-255, https://doi.org/10.1016/j.aquatox.2007.11.005, 2008.

Rink, B., Lunau, M., Seeberger, S., Stevens, H., Brinkhoff, T., Grossart, H. P., and Simon, M.: Diversity patterns of aggregateassociated and free-living bacterial communities in the German Wadden Sea, Ber Forschungszentrum Terramare, 12, 96-98, 2003.

Robinson, C. and Williams, P. J. I.: Respiration and its measurement in surface marine waters, in: Respiration in Aquatic Ecosystems, edited by: de Giorgio, P. A. and Williams, P. J. I., Oxford University Press, New York, 147-180, https://doi.org/10.1093/acprof:oso/9780198527084.003.0009, 2005.

Su, J., Dai, M., He, B., Wang, L., Gan, J., Guo, X., Zhao, H., and Yu, F.: Tracing the origin of the oxygen-consuming organic matter in the hypoxic zone in a large eutrophic estuary: the lower reach of the Pearl River Estuary, China, Biogeosciences, 14, 4085-4099, https://doi.org/10.5194/bg-14-4085-2017, 2017.

Vidoudez, C., Casotti, R., Bastianini, M., and Pohnert, G.: Quantification of dissolved and particulate polyunsaturated aldehydes in the Adriatic Sea, Mar. Drugs, 9, 500-513, https://doi.org/10.3390/md9040500, 2011.

Wang, N., Lin, W., Chen, B., and Huang, B.: Metabolic states of the Taiwan Strait and the northern South China Sea in summer 2012, J. Trop. Oceanogr., 33, 61-68, https://doi.org/10.3969/j.issn.1009-5470.2014.04.008, 2014.

Williams, P. J. I. and de Giorgio, P. A.: Respiration in Aquatic Ecosystems: history and background, in: Respiration in Aquatic Ecosystems, edited by: de Giorgio, P. A. and Williams, P. J. I., Oxford University Press, New York, 1-17, https://doi.org/10.1093/acprof:oso/ 9780198527084.003.0001, 2005.

$\mathrm{Wu}$, Z. and Li, Q. P.: Spatial distributions of polyunsaturated aldehydes and their biogeochemical implications in the Pearl River Estuary and the adjacent northern South China Sea, Prog. Oceanogr., 147, 1-9, https://doi.org/10.1016/j.pocean.2016.07.010, 2016. 
Xu, J., Li, X., Shi, Z., Li, R., and Li, Q. P.: Bacterial carbon cycling in the river plume in the northern South China Sea during summer, J. Geophys. Res.-Oceans, 123, 8106-8121, https://doi.org/10.1029/2018jc014277, 2018.

Yin, K., Lin, Z., and Ke, Z.: Temporal and spatial distribution of dissolved oxygen in the Pearl River Estuary and adjacent coastal waters, Cont. Shelf Res., 24, 1935-1948, https://doi.org/10.1016/j.csr.2004.06.017, 2004.
Zhang, H. and Li, S.: Effects of physical and biochemical processes on the dissolved oxygen budget for the Pearl River Estuary during summer, J. Mar. Syst., 79, 65-88, https://doi.org/10.1016/j.jmarsys.2009.07.002, 2010.

Zhang, Y., Xiao, W., and Jiao, N.: Linking biochemical properties of particles to particle-attached and free-living bacterial community structure along the particle density gradient from freshwater to open ocean, J. Geophys. Res.-Biogeo., 121, 2261-2274, https://doi.org/10.1002/2016jg003390, 2016. 